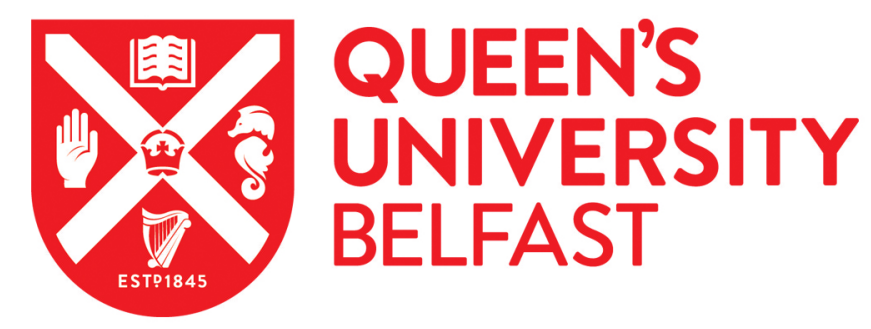

\title{
Experimental Assessment of Short Cycling in a Hybrid Photovoltaic- Thermal Heat Pump System
}

Obalanlege, M. A., Mahmoudi, Y., Douglas, R., Bailie, D., \& Davidson, J. (2020). Experimental Assessment of Short Cycling in a Hybrid Photovoltaic-Thermal Heat Pump System. Applied Energy, 268, [114916]. https://doi.org/10.1016/j.apenergy.2020.114916

\section{Published in:}

Applied Energy

\section{Document Version:}

Peer reviewed version

\section{Queen's University Belfast - Research Portal:}

Link to publication record in Queen's University Belfast Research Portal

\section{Publisher rights}

Copyright 2020 Elsevier.

This manuscript is distributed under a Creative Commons Attribution-NonCommercial-NoDerivs License

(https://creativecommons.org/licenses/by-nc-nd/4.0/), which permits distribution and reproduction for non-commercial purposes, provided the author and source are cited.

\section{General rights}

Copyright for the publications made accessible via the Queen's University Belfast Research Portal is retained by the author(s) and / or other copyright owners and it is a condition of accessing these publications that users recognise and abide by the legal requirements associated with these rights.

Take down policy

The Research Portal is Queen's institutional repository that provides access to Queen's research output. Every effort has been made to ensure that content in the Research Portal does not infringe any person's rights, or applicable UK laws. If you discover content in the Research Portal that you believe breaches copyright or violates any law, please contact openaccess@qub.ac.uk. 


\title{
Experimental Assessment of Short Cycling in a Hybrid Photovoltaic-Thermal Heat Pump System
}

\author{
Mustapha A. Obalanlege ${ }^{a}$, Yasser Mahmoudi ${ }^{a}$, Roy Douglas $^{a}$, \\ David Bailie $^{b}$ John Davidson ${ }^{b}$ \\ ${ }^{a}$ School of Mechanical and Aerospace Engineering, Queens University Belfast, Belfast, BT9 5AH, United Kingdom. \\ ${ }^{b}$ BL Refrigeration and Air Conditioning Ltd., Belfast, BT3 9LE, United Kingdom. \\ *Corresponding author: Tel: +44 (0)2890975495, email: s.mahmoudilarimi@qub.ac.uk
}

\begin{abstract}
An experiment is conducted in this paper to analyse the effect of short cycling phenomenon on the performance of a hybrid photovoltaic-thermal heat pump system. The system utilises indirect expansion to cool a photovoltaic-thermal panel through a photovoltaic-thermal water buffer tank that supplies a heat pump, providing space heating using a convection radiator. A photovoltaic-thermal module rated at $200 \mathrm{~W}$ electrically and $650 \mathrm{~W}$ thermally is generates electricity and absorbs heat to be utilized by a water-to-water heat pump with heating capacity of $7.77 \mathrm{~kW}$. The system was monitored over one-hour operating times for a range of solar irradiances $\left[250 \mathrm{~W} / \mathrm{m}^{2}-650 \mathrm{~W} / \mathrm{m}^{2}\right]$, water flow rates through the photovoltaic-thermal module $[7.3 \mathrm{l} / \mathrm{min}-17.3 \mathrm{l} / \mathrm{min}]$ and photovoltaic-thermal buffer tank water volumes [45 litres - 75 litres]. Results show the system successfully cools the photovoltaic surface by up to $33^{\circ} \mathrm{C}$. This leads to an electrical efficiency increase of up to $0.7 \%$, correlating to a $17.5 \%$ increase in generated electricity. The heat pump experiences coefficient of performance values up to 7 . Short cycling frequency increased as the solar irradiance increased. Varying water flow rates through the photovoltaic-thermal module have less influence on system performance than solar irradiance, however, increasing the flow rate from $7.3 \mathrm{l} / \mathrm{min}$ to $17.3 \mathrm{l} / \mathrm{min}$ results in the photovoltaic surface temperature reducing by $1{ }^{\circ} \mathrm{C}$ and short cycling frequency increasing. Variation in the photovoltaicthermal buffer tank water volume from 45 to 75 litres decreased the photovoltaic surface temperature by $5^{\circ} \mathrm{C}$ and increased the short cycling frequency from 6 cycles/hour to 3 cycles/hour.
\end{abstract}

Keywords: experimental; photovoltaic-thermal (PVT); heat pump; indirect expansion; short cycling; efficiency.

\section{Nomenclature}

$\underline{\text { Symbols }}$

A

Area $\left(\mathrm{m}^{2}\right)$

$\underline{\text { Subscripts }}$

$C_{p}$

Specific Heat (J/kg K)

$c$

Condenser

$d t \quad$ Discretised Time (s)

elec

Electrical

G

Irradiance $\left(\mathrm{W} / \mathrm{m}^{2}\right)$

$k$

Compressor

I Current (A)

pumps

Pumps

rad.fan

Radiator Fan 


\begin{tabular}{|c|c|c|c|}
\hline$\dot{m}$ & Mass Flow Rate $(\mathrm{kg} / \mathrm{s})$ & system & Total System \\
\hline$P$ & Power $(\mathrm{W})$ & & \\
\hline$Q$ & Heat Energy $(\mathrm{J})$ & & \\
\hline$\dot{Q}$ & Heat Power (W) & $\underline{\text { Abbreviations }}$ & \\
\hline$T$ & Temperature $\left({ }^{\circ} \mathrm{C}\right)$ & $\mathrm{CO}_{2}$ & Carbon Dioxide \\
\hline$t$ & Time (s) & $\mathrm{COP}$ & Coefficient of Performance \\
\hline$U$ & Voltage (V) & IEA & International Energy Agency \\
\hline$V$ & Volume $\left(\mathrm{m}^{3}\right)$ & IEPVT/HP & $\begin{array}{l}\text { Indirect Expansion Photovoltaic- } \\
\text { Thermal Heat Pump }\end{array}$ \\
\hline$\dot{V}$ & $\begin{array}{l}\text { Volumetric Flow Rate } \\
\left(\mathrm{m}^{3} / \mathrm{s}\right)\end{array}$ & PV & Photovoltaic \\
\hline$W$ & Work (W) & PVT & Photovoltaic-Thermal \\
\hline$\eta$ & Efficiency & $\operatorname{Re}$ & Reynolds Number \\
\hline
\end{tabular}

\section{Introduction}

Energy efficiency has grown in importance in recent history and becomes a key focus in the climate change discussion and the global mission to reduce carbon emissions [1]. The International Energy Agency (IEA) recognise that "efficiency can enable economic growth, reduce emissions and improve energy security" [2]. Efficiency policies alone could reduce current emission by 40\% [2]. Between 2000 and 2017, the reduction in global energy use due to increased efficiency was $12 \%$ [2]. The importance of energy efficiency goes beyond that of just environmental impact. Increasing the energy efficiency serves to reduce the burden of energy consumption on developing countries by reducing its economic costs [2] as well as the health costs from pollutants generated by burning fossil fuel [2]. Globally the sale of heating, ventilation and air conditioning systems have been rising to facilitate the need to control internal temperatures [3]. Heat pump and renewable heating has seen a growth rate of approximately 5\% every year since 2010 [4]. The IEA has estimated that high-efficiency heating technologies will lead to a reduction of $3.5 \%$ in the average global heating energy intensity, every year [4]. Heat pumps are an example of a relatively high efficiency heating system [5]. Even with nearly 20 million heat pumps purchased globally in 2018, they only meet less than $3 \%$ of the global domestic heating demand [4].

Unlike heat pumps, solar thermal heating does not rely on any previously generated power (such as electricity) to produce heat [6]. Solar thermal heating converts the Sun's rays into useable heat onsite. Within the last decade, the global installed solar thermal heat capacity has increased by $250 \%$ and has a rated heating capacity of just over $470 \mathrm{GW}$ [4]. Though this still only equated to meeting $2.1 \%$ of global space heating and water production [4]. However, in Europe, most solar energy systems are designed to convert sunlight into electricity [7], known as solar photovoltaic (PV) systems. Solar photovoltaic (PV) panels are typically no more than $20 \%$ efficient in electricity generation [8]. The rest of the absorbed sunlight rays are converted into heat [8]. In PV panels, the generated heat increased the temperature of the panel, resulting in a decrease of its electrical efficiency [9]. Due to this temperature influence on the performance of PVs, the energy that is not converted into electricity by the PV panels must be extracted to prevent excessive heating of the PV cells 
and prevent performance deterioration [6]. PV panels can be actively cooled by passing a fluid through the rear of the panel [10]. It then becomes possible to extract both heat and electrical power [10]. This combined solar heat and electrical power system is known as a Photovoltaic-Thermal (PVT) system [11]. The fluid that passes through the PVT module absorbs the excess heat and thus reduces the PV temperature $\left(T_{P V}\right)$. This keeps the PVT system relatively cool to prevent reduction in the electrical efficiency of the PV [12]. The heated fluid is then used for thermal related energy consumption (e.g. [7, 9, 13]). PVT modules generate less thermal energy than solar-thermal collectors and less electricity than PV panels under the same conditions [7]. Nonetheless, the combined power output by a PVT module is greater than power output of a similar sized PV panel or solar-thermal collector under similar conditions [7].

With the UK committing to a net carbon neutral goal by 2050 [14], and many other countries promising to reduce carbon emission via the Paris Agreements [15], it is important to reduce carbon emissions from space heating and water heating, which accounts for $83 \%$ of the total energy consumption in homes in the UK [16]. In 2017 electricity and heating in buildings was responsible for $25 \%$ of $\mathrm{CO}_{2}$ emissions that year [17]. Work has been done in trying to combine solar energy and heat pump technology to improve system efficiency, especially with the rapid growth of solar thermal and solar PV installation [7]. Solar thermal and solar PV have seen a global average annual growth of $45.7 \%$ between 2000 and 2018 [18]. It is known that combining solar and heat pump technology can work to increase the performance and efficiency of the technologies [19]. Though there are over ninety known combined solar heat pump systems in Europe, their performance has not yet been systematically evaluated [19]. As such, it has been recommended that the evaluation of these systems should lead to the development of high efficiency systems and reliable solutions to technical challenges [19].

A promising solution to the combination of solar energy to heat pumps is through Indirect Expansion PVT Heat Pump (IEPVT/HP) systems [20, 21, 22]. The IEPVT/HP system is designed to generate, to a high level of efficiency, both electricity and heat [23]. These systems combine solar PVT modules with heat pumps via a low-volatility fluid (e.g. water) [6]. Sunlight is shone onto the PV surface, which converts part of the light into electricity to be stored in a battery or directly used; a larger portion of the sunlight is converted into heat [11]. Cool water is pumped through the PVT module thus cooling the PVT system and maintaining a high electrical conversion efficiency [6]. The heated water is transported to the evaporator of the heat pump, where it provides the energy required for the heat pump. The heat generated by the heat pump can be used for space heating. In comparison to direct expansion technology, the indirect expansion approach allows for ease of installation and maintenance on domestic sites [22].

The IEPVT/HP system can increase the overall efficiency of heat and electricity generation in comparison to the individual PV panel of equivalent area and air source heat pump [22]. However, limited experimental research has taken place on such systems [22]. Cai et al. [24] presented experimental and numerical work on an indirect expansion solarassisted multi-functional heat pump tested by a solar simulator. They [20] used an experimental rig to validate a numerical code that was used to study the system. Cai et al. [20] were able to show that there is an observable increase in the heat pump performance as 
solar irradiance rises. They [20] experienced a 0.22 rise in their coefficient of performance (COP) as the solar irradiance rose from $0 \mathrm{~W} / \mathrm{m}^{2}$ to $800 \mathrm{~W} / \mathrm{m}^{2}$. Cai et al. [20] also suggest that in order to balance the heat capacity of the system and the COP, the mass flow rate through the evaporator should be adjusted depending on the temperature demand and heat load. However, it should be noted that their system [20] only produced heat and no electricity was produced. Wang et al. [21] also developed an indirect-expansion solar-assisted multifunctional heat pump. They [21] concluded that the system can operate at high efficiencies during winter on the condition the solar irradiance is also high (i.e. clear skies). However, as solar irradiance data was not reported, and heating elements used to simulate solar heating at times, it is not possible to identify the effect of the solar energy on the system performance. Besgani et al. [25] conducted an experimental study on a dual-source solarassisted IEPVT/HP system in Milan, Italy, on a detached prefabricated building. Seven PVT panels and one PV panel were used to compare the two different technologies. The PVTs were cooled using water and transferred to the heat pump via a water-based evaporator. The heat pump also used an air-based evaporator to use air as another heat source. Besgani et al. [25] found that the water-source operation of the heat pump outperformed the air-source operation by $34 \%$, and that the water-source heat pump did not require any defrost cycling. It was also observed that the electricity production of the PV and PVT panels were similar [25]. They concluded that their IEPVT/HP system has an average COP of 3 [25]. In another experimental study in Lyngby, Denmark, Dannemand et al. [26] analysed the performance of a solar IEPVT/HP system for nine months. Dannemand et al. [26] demonstrated that their system could operate and absorb solar energy at solar radiation intensities greater than 50 $\mathrm{W} / \mathrm{m}^{2}$ and act as an air source heat absorber at solar radiation intensities less than $50 \mathrm{~W} / \mathrm{m}^{2}$ [26]. Though the system was proved to work, the researchers concluded that optimisation of the system is important [26].

The role of renewable energy integration with heat pumps is important to understand as heat pump efficiency can be influenced by the heat demand of the household or heat supply required by the heat pump. A heat pump compressor shuts off once the room it has been heating reaches the set temperature. If the room temperature drops below the set temperature, the compressor restarts to raise the temperature again. If this occurs multiple times in a short period of time, it is called short cycling [27]. Short cycling occurs primarily due to the variable heat demand. It can also occur when the heat supply to the heat pump becomes too low for the heat pump to safely operate, causing the heat pump to shut off. This allows time for the heat source to increase in temperature, allowing the heat pump to operate again. If this occurs several times in a short period of time, then this is also short cycling but due to heat supply. Waddicor et al. [27] was able to show that there is a decrease in the COP of the heat pump from steady state predictions due to the intermitting switching on and off of the heat pump during short cycling. It is also stated that short cycling reduces the compressor reliability in heat pumps and the electrical supply systems [27]. Renewable energy sources, especially solar energy, are known to be intermittent, and as such are not a source of consistent energy [28]. This means that a heat pump system integrated with a solar energy system will experience periods when the solar energy supply is below the requirements of the heat pump to operate continuously. One way of possibly reducing this effect is with the use of buffer tanks [27]; however, the effect of buffer tanks in IEPVT/HP 
systems has not been experimentally studied. Another solution would be to integrate solar heat sources with other sources such as air or ground [24]. However, it is important to understand the operation of the solar source in different conditions as this knowledge can be used to optimise the integration of multiple sources into one system.

Previous experimental and modelling research on hybrid PVT and heat pump systems utilising indirect expansion techniques have made significant contribution to the area. However, there have been no studies on the effect of short cycling phenomenon on the performance of the hybrid system. Present work aims at filling these gaps through comprehensive experimental tests and will add the following novelty to this growing body of knowledge in this field:

1) This paper will for the first time, analyses the influence of the short cycling phenomenon on the electrical and thermal efficiencies of the PVT as well as on the coefficient of performance of the heat pump in a hybrid PVT heat pump system. Short cycling analysis enables us to understand (i) the influence of the solar intermittency on the system's electrical and thermal performance [23] (ii) analyse the capability of the system's flexible parameters to suppress the solar energy intermittency (iii) optimise the design of the system's parameters in order to minimise the impact of the intermittency on the long-term operation of the system.

2) In the literature there is a lack of experimental data on the influence of the water flow rate through the PVT panel on the electrical and thermal performance of the hybrid system. Water flow rate controls the flow regime in the PVT pipe to be laminar or turbulent, which controls the rate of heat transfer from the PVT surface to the water, and hence on the performance of the PVT and the whole hybrid system. Therefore, this paper will for the first time, studies experientially the influence of laminar, transitional and turbulent flow regimes in the PVT pipe, on the performance of the hybrid system.

3) This paper will demonstrate for the first time the significance of the PVT water tank volume on the performance of the hybrid system. PVT water tank volume controls the rate of change in the temperature of the water in the PVT water tank, hence enabling us to understand the influence of the rate of change in temperature of water cooling the PVT module and the water supplying the heat pump with heat. Such analyses will eventually contribute to a smarter design of control systems for such indirect expansion photovoltaic-thermal heat pump (IEPVT/HP) technologies for domestic applications.

Therefore, the main objective of this study is to experimentally analyse the performance and efficiency of an IEPVT/HP system under short cycling conditions. This is achieved by experimentally controlling and analysing the variation of key parameters that influence the performance of the system, including solar irradiance, the PVT water flow rate and the volume of the PVT water tank. Solar irradiance represents a parameter that is dictated by the environment and location. The PVT water tank volume represents a parameter important to the design considerations of the IEPVT/HP system, and the PVT water flow rate represents a parameter that is programmable and changeable after the installation and 
implementation of the system. The present work will add novel experimental evidence in order to improve significantly the energy efficiency of renewable systems supporting the pathways to decarbonise the heating in buildings.

\section{System Description}

The IEPVT/HP system developed in this work consists of three main operational loops, including the heat intake loop, the heat pump loop, and the heat rejection loop as shown in Fig. 1. The image of the real experimental setup is given in Fig. 2. The stages of the system are as follows:

- The heat intake loop comprises of a solar simulator producing light normally to the surface of the solar PVT module. The solar PVT is cooled by water that is pumped from the PVT water tank to the PVT. This also increase the temperature of the water flowing through it. After cooling the PVT module, the water flows into the PVT water tank. Water from the PVT water tank is then pumped through the heat pump evaporator thus transferring heat into the heat pump loop. This is a closed loop, so no water is lost nor gained in this cycle.

- The heat pump loop cycles the refrigerant in the subcooled or two-phase state through the evaporator to absorb heat from the water in the heat intake loop. The refrigerant becomes a saturated gas and enters a gas compressor. The compressor raises the pressure and temperature of the refrigerant to a superheated state. As the refrigerant passes through the condenser, it transfers heat to the heat rejection loop before passing through the thermal expansion valve. The thermal expansion valve returns the refrigerant to its two-phase form before restarting the loop. This is a closed loop, so no refrigerant is lost or gained in the loop.

- The user loop pumps water through the condenser to be heated to a temperature higher than the ambient temperature of the environment to be heated. The heated water is pumped through a convection radiator with air blown over the radiator to increase heat transfer. The heated water transfers heat to the air passed over it, which is blown into the environment to be heated, thus cooling the heated water. After the water has passed through the radiator, it is pumped into the condenser water tank where it restarts the cycle. This is a closed loop, so no water is lost or gained in the loop. 


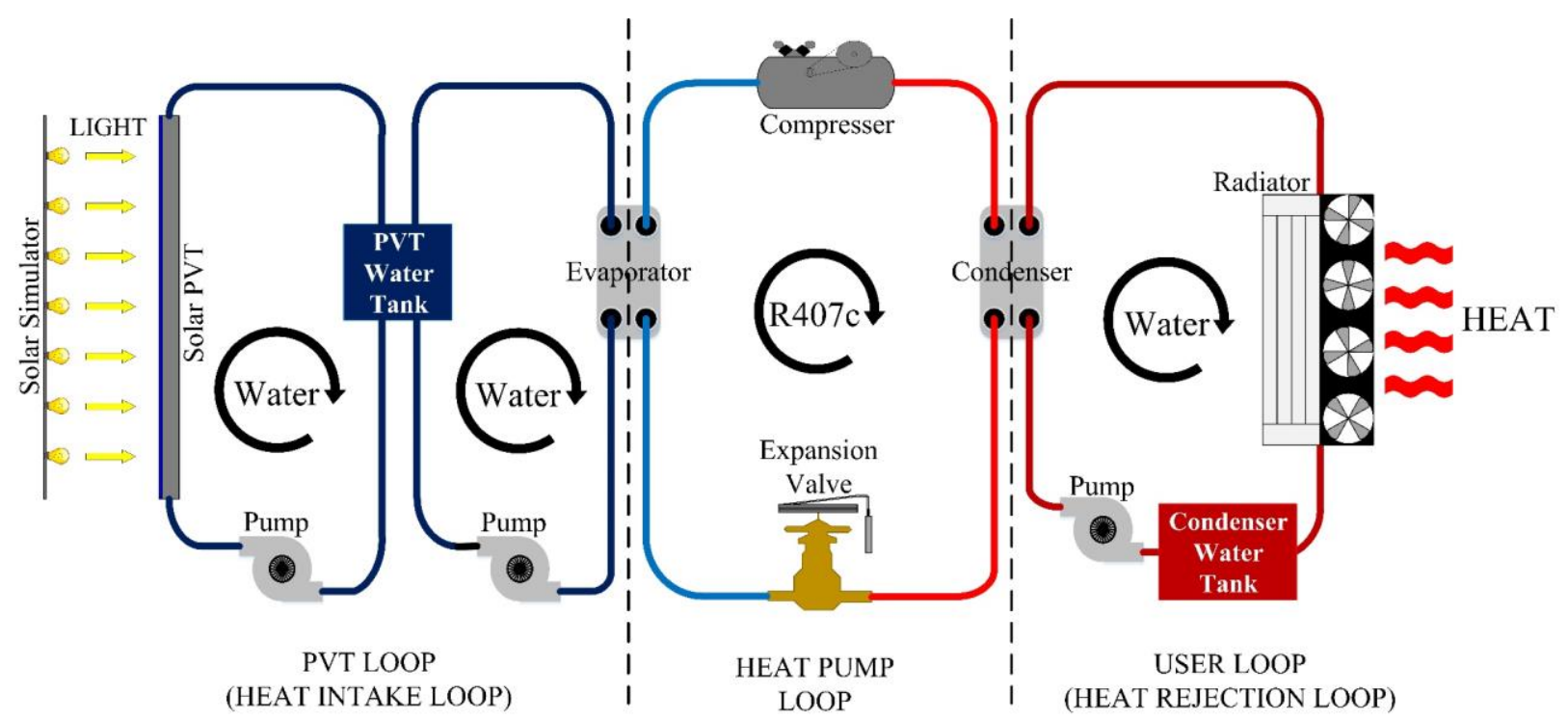

Fig. 1. Diagram of indirect expansion photovoltaic-thermal heat pump (IEPVT/HP) system.

The solar simulator used in this work utilised 28 metal halide tungsten filament bulbs (OSRAM Ultra Vitalux) to generate light in the ultraviolet, visible and infrared spectrum, similar to that found in sunlight. They were spaced $250 \mathrm{~mm}$ orthogonally to create a $7 \times 4$ bulb array. The solar simulator is placed opposite the PVT module as shown in Fig. 3. The PVT module (Solimpeks PowerVolt) has an aperture area of $1.326 \mathrm{~m}^{2}$. The PVT was installed in a landscape orientation on a vertical wall, $90^{\circ}$ to horizontal. The solar irradiation was controlled by adjusting the distance between the solar simulator and the PVT module in accordance with the inverse square law of light [29] and the solar irradiation measurements taken parallel to the PVT module face. The PV cells' manufacturer rated nominal electrical conversion efficiency (at standard PV temperature of $25^{\circ} \mathrm{C}$, standard irradiance of 1000 $\mathrm{W} / \mathrm{m}^{2}$, spectrum profile of AM 1.5 ) was $15.06 \%$ with a power tolerance of $\pm 33 \%$, meaning the measured nominal conversion efficiency could vary from $10.1 \%$ to $20.1 \%$. The solar PV cells have a manufacturer rated temperature correction factor of $-0.45 \% /{ }^{\circ} \mathrm{C}^{1}$. The PVT module is pictured opposite the solar simulator in Fig. 3. The heat pump used is the Aermec Venice $20 \mathrm{H}$. The Aermec Venice $20 \mathrm{H}$ is rated by the manufacturer to have a heating capacity of $7.77 \mathrm{~kW}$ with a compressor input power of $2.59 \mathrm{~kW}$ and a COP of 3. The heat pump utilises a scroll compressor and its working fluid/refrigerant is R407c. The power source of the heat pump feeds the heat pump cycle and the circulator water pump on the evaporator. The heat pump is pictured with the convection radiator, PVT water tank and condenser water tank in Fig. 4.

\footnotetext{
${ }^{1}$ The calculated temperature correction factor for the condition of the present experiment is $-0.79 \% /{ }^{\circ} \mathrm{C}$. While the manufacturer rating of $-0.45 \% /{ }^{\circ} \mathrm{C}$ was obtained under standard conditions (i.e. $1000 \mathrm{~W} / \mathrm{m}^{2}$ irradiance and PVT maintained at $\left.25^{\circ} \mathrm{C}\right)$.
} 


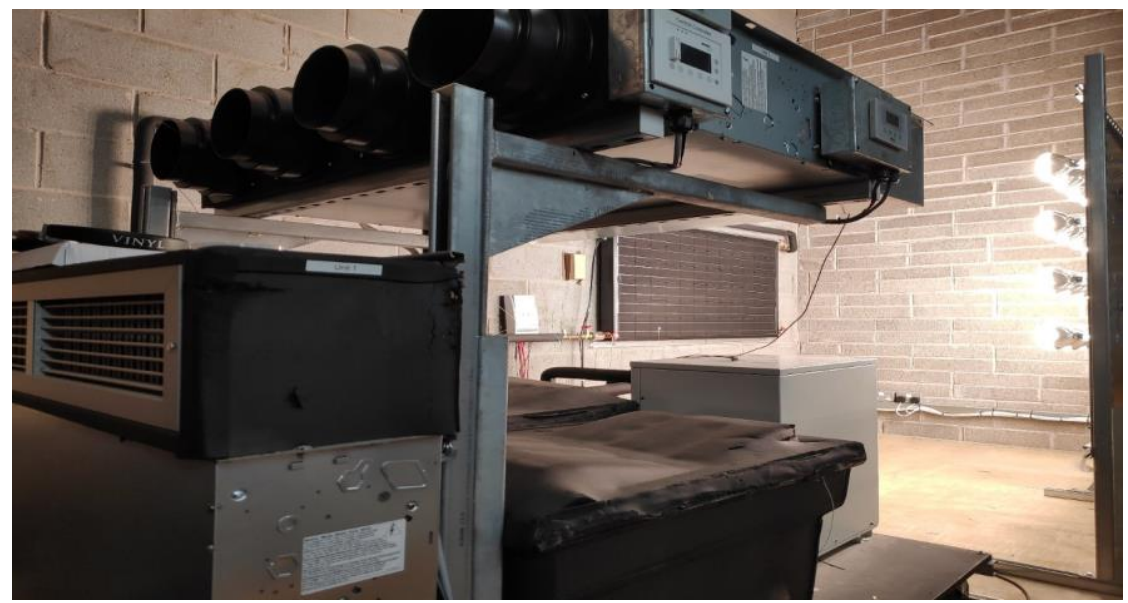

Fig. 2. Image of the experimental rig.

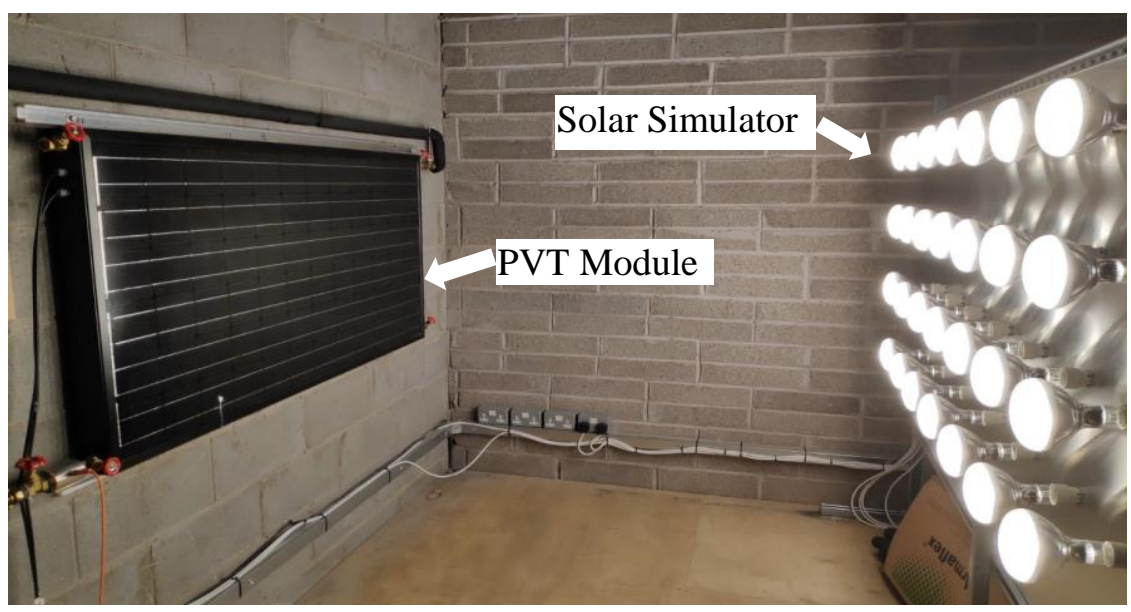

Fig. 3. Image of solar PVT module and solar simulator.

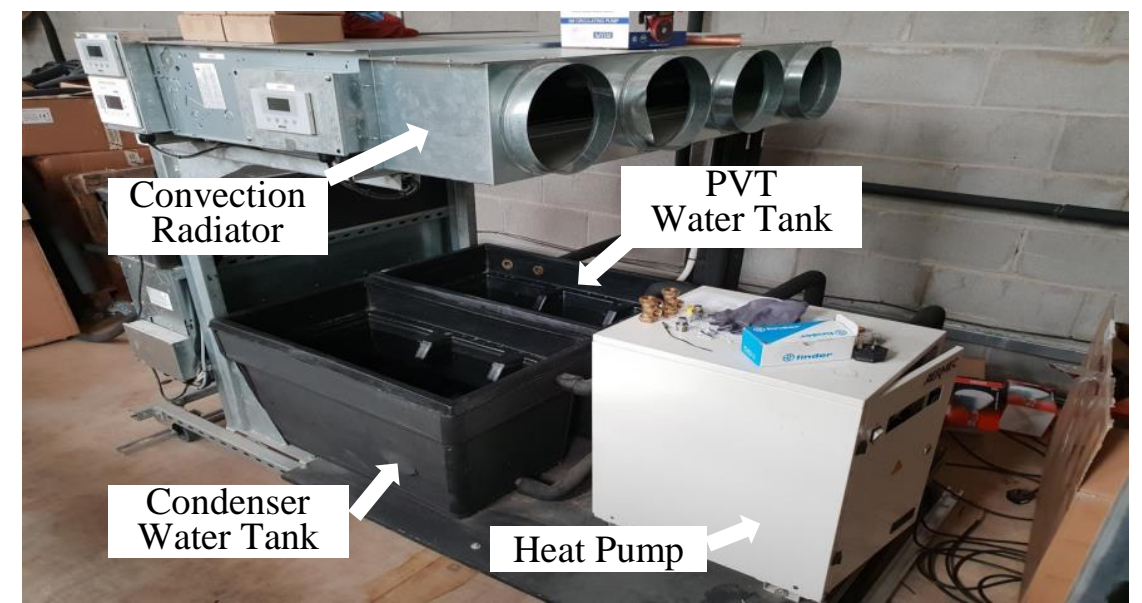

Fig. 4. Image of heat pump, PVT water tank, condenser water tank and convection radiator. 


\subsection{Measurement System}

K-type thermocouples were used to measure all water temperatures reported as well as the ambient air temperatures around the experimental rig and were recorded using a thermocouple data logger (PicoTech TC-08) at $1 \mathrm{~Hz}$. The surface temperature of the PV surface was measured using the FLIR T640 thermal imaging camera. The voltage of the heat pump, water pumps and PV panel were measured using differential oscilloscope probes (PicoConnect 442) and recorded using an oscilloscope (PicoScope 4444) at $1 \mathrm{MHz}$. The heat pump and water pump currents were measured using current clamps (PicoTech TA018 60A) and recorded using an oscilloscope (PicoScope 2204A) at $1 \mathrm{MHz}$. The reported flow rates were measured using an electromagnetic flowmeter (ifm SM7000). The reported irradiances were measured using a photometer (RS Pro ISM400). The associated measurement uncertainties are given in Table 1.

Table 1: Measurement uncertainties.

\begin{tabular}{lll}
\hline Parameter & Measurement Device & Uncertainty \\
\hline Water Temperature & K-type thermocouple & $\pm 0.2 \%\left({ }^{\circ} \mathrm{C}\right)$ \\
\hline Air temperature & K-type thermocouple & $\pm 0.2 \%\left({ }^{\circ} \mathrm{C}\right)$ \\
\hline PV Surface Temperature & Thermal Imaging Camera & $\pm 2 \%\left(\right.$ at $\left.25^{\circ} \mathrm{C}\right)$ \\
\hline Voltage & Differential Oscilloscope Probe & $\pm 2 \%(\mathrm{~V})$ \\
\hline Current & Current Probes (Clamps) & $\pm 2 \%(\mathrm{I})$ \\
\hline Water Flow Rate & Electromagnetic Flow Meter & $\pm 2 \%(1 / \mathrm{min})$ \\
\hline Irradiance & Photometer & $\pm 5 \%\left(\mathrm{~W} / \mathrm{m}^{2}\right)$ \\
\hline
\end{tabular}

\section{Experimental Method and Operation}

The tests were carried out over a one-hour operation time when the system had reached a cyclical condition (i.e. short cycling). The cyclical operation is due to the mismatch in the power of the heat pump and the thermal energy supplied by the PVT. The compressor is programmed to shut off (enter off-cycle) when the water entering the evaporator reaches $8^{\circ} \mathrm{C}$. The compressor will then turn back on once the water entering the evaporator reaches $10^{\circ} \mathrm{C}$. It should be noted that the water continues to flow through the evaporator and the condenser whether the compressor is switched on or off. Additionally, the fan continues to operate in the convection radiator when the compressor shuts off. The study focuses on the effects of varying these parameters; (i) the solar irradiance between $250 \mathrm{~W} / \mathrm{m}^{2}, 450 \mathrm{~W} / \mathrm{m}^{2}$ and $650 \mathrm{~W} / \mathrm{m}^{2}$; (ii) the water flow rate through the PVT module between $7.3 \mathrm{l} / \mathrm{min}, 13.2$ $1 / \mathrm{min}$ and $17.3 \mathrm{l} / \mathrm{min}$ which correspond to laminar $(\operatorname{Re}=1700)$, transitional $(\operatorname{Re}=3050)$ and turbulent $(\mathrm{Re}=4100)$ flow through the PVT module respectively; and (iii) the PVT water tank volume between 45 litres, 60 litres and 75 litres.

\subsection{Performance Metrics}

The performance of the system was evaluated using measured data (such as temperature) as well as calculated metrics using Equations (1-7) listed in Table 2. 
Table 2: Calculated performance metric equations.

\begin{tabular}{|c|c|c|}
\hline Performance Metric & Equation Used & \\
\hline PVT Electrical Power Output & $P_{\text {elec }}=U I$ & (1) \\
\hline $\begin{array}{l}\text { Heat Pump Compressor Electrical } \\
\text { Power Consumption }\end{array}$ & $\bar{W}_{k}=\frac{1}{\Delta t} \int_{t_{1}}^{t_{2}} U I d t$ & (2) \\
\hline Condenser Heat Output & $\dot{Q}_{c}=\dot{m} C_{p}\left(T_{1}-T_{2}\right)$ & (3) \\
\hline Total Condenser Heat Output & $Q_{c}=\int_{t_{1}}^{t_{2}} \dot{Q}_{c} d t$ & (4) \\
\hline PVT Electrical Efficiency & $\eta_{\text {elec }}=\frac{\bar{P}_{\text {elec }}}{I A}$ & (5) \\
\hline $\begin{array}{l}\text { Instantaneous Heat Pump } \\
\text { Coefficient of Performance (COP) }\end{array}$ & $C O P_{H P}=\frac{\dot{Q}_{c}}{\bar{W}_{k}}$ & (6) \\
\hline $\begin{array}{l}\text { Instantaneous IEPVT/HP System } \\
\text { Coefficient of Performance (COP) }\end{array}$ & COP $P_{\text {system }}=\frac{\dot{Q}_{c}+\bar{P}_{\text {elec }}}{\bar{W}_{k}+\bar{P}_{\text {pumps }}+\bar{P}_{\text {rad.fan }}}$ & (7) \\
\hline
\end{tabular}

\section{Results and Discussion}

In this Section, the results from the experimental operation of the IEPVT/HP rig are given. The results include an initial assessment of the uncooled PV under different irradiances to provide a reference for the cooled performance of the PV. Then, the results are presented for variations in solar irradiance (Section 4.1), volumetric flow rate through the PVT module (Section 4.2) and the water volume in the PVT water tank (Section 4.3). The results given in Table 3 are for the PV surface that is uncooled by the PVT module. The PV surface was exposed to irradiances of $250 \mathrm{~W} / \mathrm{m}^{2}, 450 \mathrm{~W} / \mathrm{m}^{2}$ and $650 \mathrm{~W} / \mathrm{m}^{2}$.

Table 3: Results for uncooled PV surface.

\begin{tabular}{llll}
\hline Irradiance $\left(\mathbf{W} / \mathbf{m}^{\mathbf{2}}\right)$ & $\begin{array}{l}\text { PV Surface } \\
\text { Temperature }\left({ }^{\circ} \mathbf{C}\right)\end{array}$ & $\begin{array}{l}\text { Electricity } \\
\text { Production }(\mathbf{W})\end{array}$ & $\begin{array}{l}\text { Electrical } \\
\text { Efficiency }(\%)\end{array}$ \\
\hline $\mathbf{2 5 0}$ & 47.3 & 17 & 5.1 \\
$\mathbf{4 5 0}$ & 63.3 & 27 & 4.5 \\
$\mathbf{6 5 0}$ & 70.4 & 35 & 4.0 \\
\hline
\end{tabular}

Table 3 shows a non-linear increase in the PV temperature as the irradiance increased. The PV temperature increased by $33.8 \%$ between $250 \mathrm{~W} / \mathrm{m}^{2}$ and $450 \mathrm{~W} / \mathrm{m}^{2}$, however the PV temperature only increased by $9.7 \%$ between $450 \mathrm{~W} / \mathrm{m}^{2}$ and $650 \mathrm{~W} / \mathrm{m}^{2}$. The electricity produced also demonstrates a non-linear increase with the increase in irradiance. The electricity production increased by $58.8 \%$ from $250 \mathrm{~W} / \mathrm{m}^{2}$ to $450 \mathrm{~W} / \mathrm{m}^{2}$, while the electricity 
production only increased by $22.9 \%$ from $450 \mathrm{~W} / \mathrm{m}^{2}$ to $650 \mathrm{~W} / \mathrm{m}^{2}$. Hence, there is a connection between the PV temperature and the electricity produced by the PV panel. Table 3 shows a decrease in electrical efficiency as the PV temperature rises.

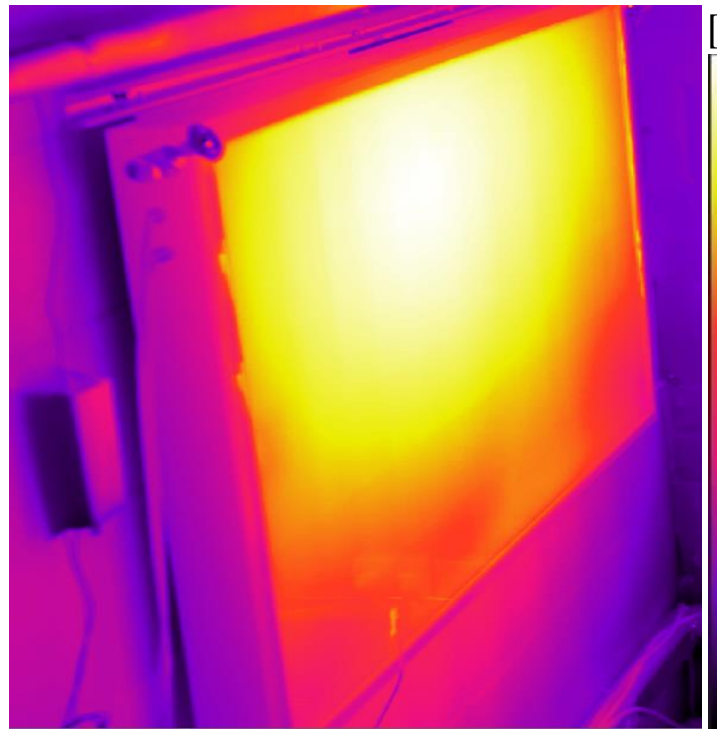

Fig. 5. Thermographic image of uncooled PVT module under $650 \mathrm{~W} / \mathrm{m}^{2}$ simulated solar irradiance with an average surface temperature of $71^{\circ} \mathrm{C}$.

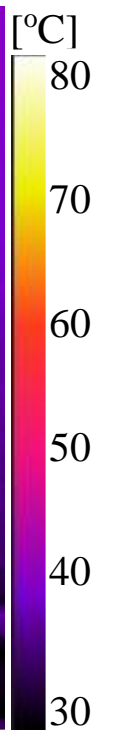

Fig. 6. Thermographic image of PVT module under $650 \mathrm{~W} / \mathrm{m}^{2}$ simulated solar irradiance cooled by $17.31 / \mathrm{min}$ water flow rate with an average surface temperature of $38^{\circ} \mathrm{C}$.

A $58.8 \%$ increase in PV temperature between $250 \mathrm{~W} / \mathrm{m}^{2}$ and $450 \mathrm{~W} / \mathrm{m}^{2}$ correlates to an $11.8 \%$ decrease in electrical efficiency, while a $22.9 \%$ increase in the PV temperature between $450 \mathrm{~W} / \mathrm{m}^{2}$ and $650 \mathrm{~W} / \mathrm{m}^{2}$ correlates to an $11.1 \%$ decrease in the electrical efficiency. This experimentally demonstrates the loss of electrical efficiency in the PV panel as the PV surface temperature increased. The thermographic images of the uncooled PVT module and the cooled PVT module are given in Fig. 5 and Fig. 6, respectively. A comparison between these two figures clearly demonstrates the significant influence of the developed hybrid IEPVT/HP system in cooling the PVT panels.

\subsection{Solar Irradiance}

The results given in this subsection compare the IEPVT/HP system in operation over one hour under different irradiance exposures. The irradiances used were $250 \mathrm{~W} / \mathrm{m}^{2}, 450 \mathrm{~W} / \mathrm{m}^{2}$ and $650 \mathrm{~W} / \mathrm{m}^{2}$. In these experimental tests, the volumetric flow rate $(\dot{V})$ is kept at $17.3 \mathrm{l} / \mathrm{min}$ and the water volume $(V)$ in the PVT water tank was kept at 75 litres. Fig. 7 shows the PV surface temperature demonstrating that the IEPVT/HP system can successfully cool the PV surface. The broken lines represent the uncooled PV surface temperature, whilst the solid lines represent the PV surface temperature as the PVT module is being cooled. The figure shows that the system cools the PV surface at $250 \mathrm{~W} / \mathrm{m}^{2}, 450 \mathrm{~W} / \mathrm{m}^{2}$ and $650 \mathrm{~W} / \mathrm{m}^{2}$ by $47 \%, 44 \%$ and $38 \%$ respectively. Fig. 7 also show an increase in the PV surface temperature cooling as the solar irradiance increased. The maximum cooling difference occurs at 650 
$\mathrm{W} / \mathrm{m}^{2}$ where there is a temperature reduction of approximately $33^{\circ} \mathrm{C}$. While the minimum cooling difference occurs at $450 \mathrm{~W} / \mathrm{m}^{2}$ where the temperature is reduced by approximately $18^{\circ} \mathrm{C}$. This effect was also reported in the modelling work of Obalanlege et al. [23].

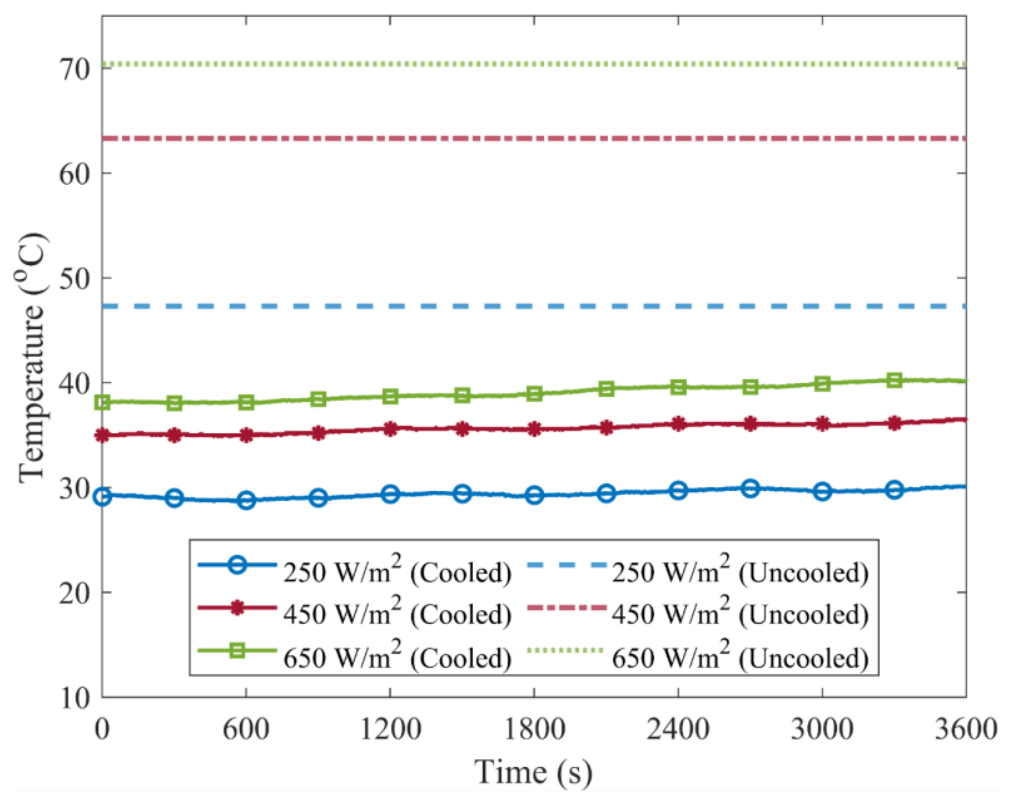

Fig. 7. PV surface temperature for different solar irradiances with $\dot{V}=17.3 \mathrm{l} / \mathrm{min}$ and $V=75$ litres.

Fig. 8 shows the water temperature before it enters the PVT module in broken lines and the water temperature at the exit of the PVT module in solid lines. The $650 \mathrm{~W} / \mathrm{m}^{2}$ experimental run shows an exit water temperature that is $0.3^{\circ} \mathrm{C}$ higher than the $450 \mathrm{~W} / \mathrm{m}^{2}$ experimental run and $0.5^{\circ} \mathrm{C}$ higher than the $250 \mathrm{~W} / \mathrm{m}^{2}$ experimental run. This is an expected result as the higher irradiance provides more energy per unit area that is converted into heat, thus causing the water temperature to rise more rapidly as it passes through the PVT module. This is also evident by the larger temperature gap between the inlet water temperature and the exit water temperature for the $650 \mathrm{~W} / \mathrm{m}^{2}$ case in comparison to the $450 \mathrm{~W} / \mathrm{m}^{2}$ and 250 $\mathrm{W} / \mathrm{m}^{2}$ cases. This experimentally demonstrates the increasing rate of water heating through the PVT module as the irradiance increased. Furthermore, Fig. 8 shows the effect of the short cycling on the water temperature difference through the PVT module. As the irradiance increased, the frequency of the operating cycles increased. The cooling part of the cycles (negative gradients), are similar for different irradiances representing a similar rate of cooling. However, the heating part of the cycle shows a higher gradient for higher irradiance, meaning the increase in the rate of heat absorption as the irradiance increased. This means that the system reaches the temperature required for the heat pump to turn on in shorter time as the irradiance increased. This will lead to an increase in the frequency of short cycling in the system for high solar irradiances. 


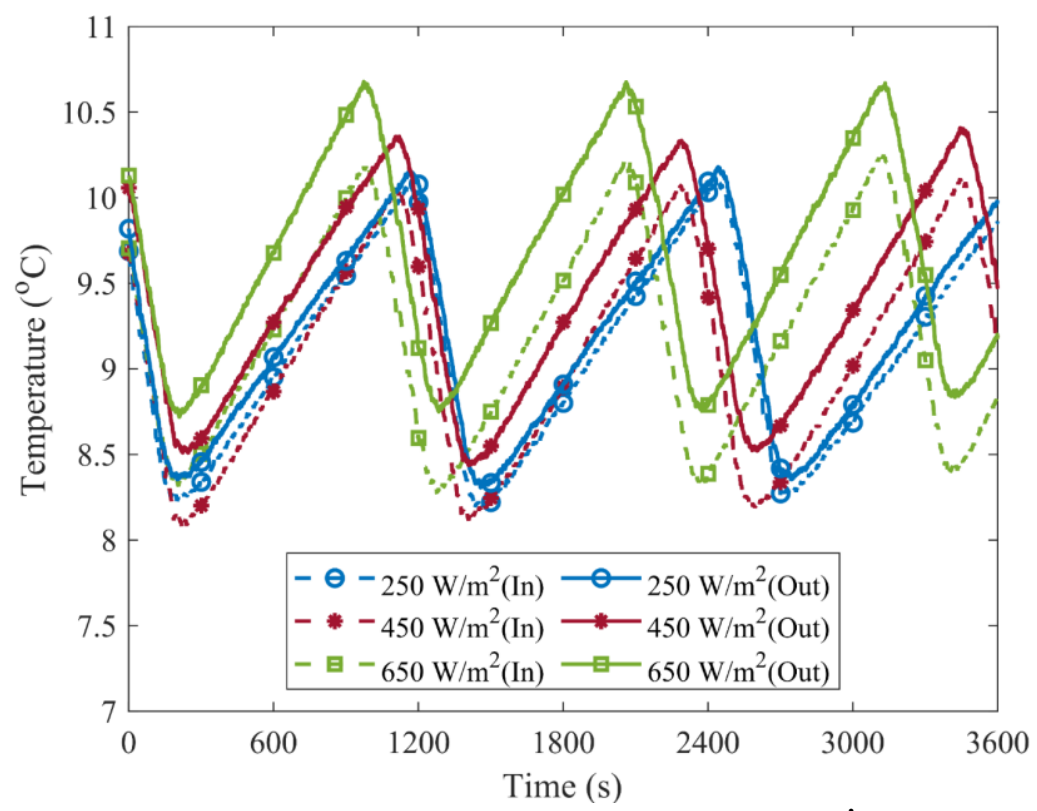

Fig. 8. PVT water temperature for different irradiances with $\dot{V}=17.31 / \mathrm{min}$ and $V=75$ litres.

The cycling effect seen in the PVT water tank temperature in Fig. 9 accounts for the effect seen in Fig. 8, since the PVT water tank is the source of the water entering the PVT module. The cooling section of the cycling (negative gradient) is parallel for changing irradiances, showing no change in the rate of heat absorption by the heat pump from the PVT water tank. The heating section of the cycling (positive gradient) shows the increase in the rate of heating from the PVT module. This increase in temperature gradient is linked to the higher water exit temperature from the PVT module at higher irradiances shown in Fig. 8. Hence, it is expected that the PVT water tank temperature increase more rapidly as irradiance increased. Furthermore, Fig. 9 shows that the PVT water tank reaches a maximum temperature of $10^{\circ} \mathrm{C}$ and a minimum temperature of $8^{\circ} \mathrm{C}$. This occurs as the heat pump is programmed to stop cooling when the water entering the evaporator drops below $8^{\circ} \mathrm{C}$ and to restart when the water entering the evaporator rises above $10^{\circ} \mathrm{C}$. This prevents the evaporator from freezing due to cooling the water to its freezing point. 


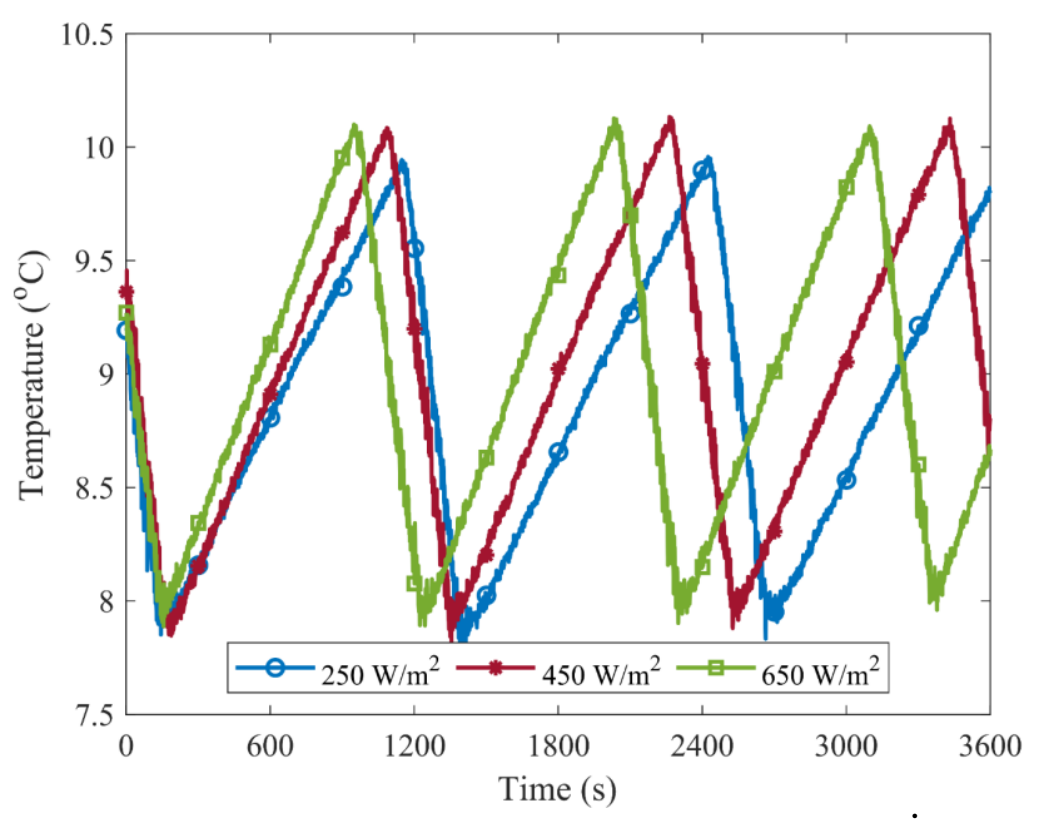

Fig. 9. PVT water tank temperature for different irradiances with $\dot{V}=17.3 \mathrm{l} / \mathrm{min}$ and $V=75$ litres.

Fig. 10 shows the electrical power output of the cooled PV panel calculated using Eq. (1) in Table 2. The highest electrical output is $\sim 40 \mathrm{~W}$ for $650 \mathrm{~W} / \mathrm{m}^{2}$ irradiance, followed by $\sim 31 \mathrm{~W}$ for $450 \mathrm{~W} / \mathrm{m}^{2}$, with the lowest value of $\sim 21 \mathrm{~W}$ for $250 \mathrm{~W} / \mathrm{m}^{2}$. This shows a near linear increase in power output with a linear increase in the irradiance. This increase in electricity generated is expected, as there is more energy to convert with increased irradiance.

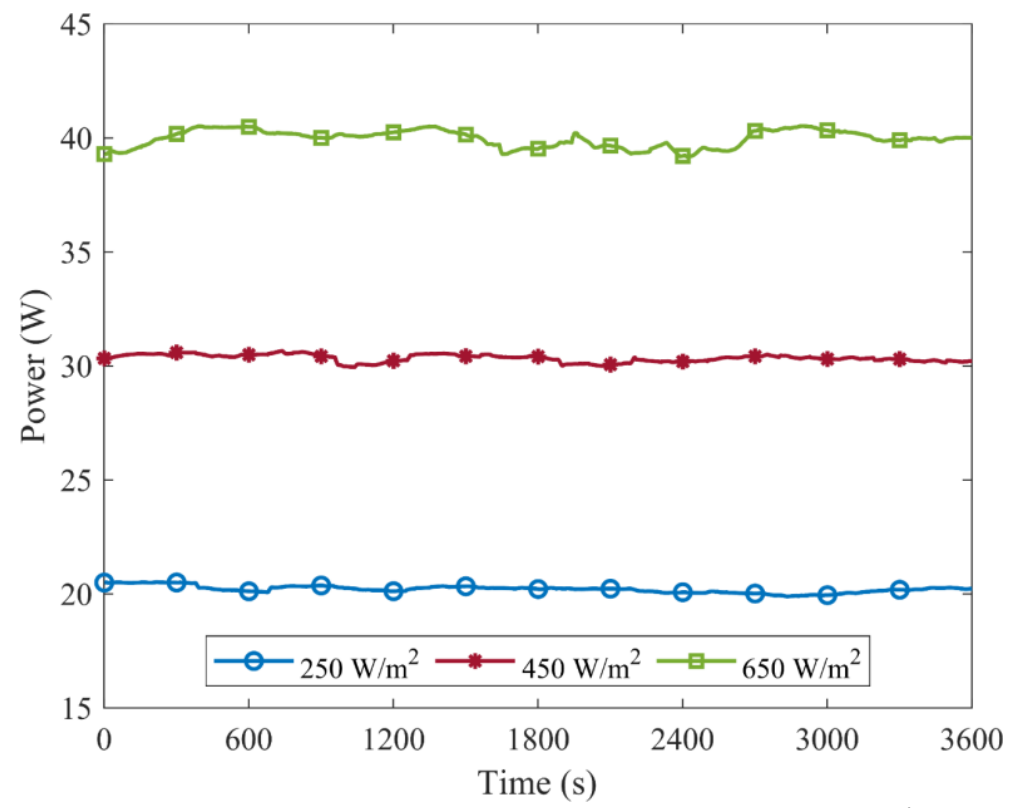

Fig. 10. PV electricity production for different irradiances with $\dot{V}=17.31 / \mathrm{min}$ and $V=75$ litres.

Fig. 11 graphs the electrical efficiency of the PV panel calculated using Eq. (5) in Table 2. The efficiencies of the uncooled PVT are shown in broken lines and the solid lines show the efficiencies of the cooled PVT. The figure shows that the system successfully increased the electrical efficiency of the PV panel by cooling it. It is seen that for $250 \mathrm{~W} / \mathrm{m}^{2}, 450 \mathrm{~W} / \mathrm{m}^{2}$ 
and $650 \mathrm{~W} / \mathrm{m}^{2}$ irradiances, the electrical efficiency of the PV increased by $1.4 \%, 0.8 \%$ and $0.7 \%$, respectively. This corresponds to a $27.5 \%, 17.8 \%$ and $17.5 \%$ increase, respectively in the electrical power generated by the PV panel. Fig. 11 also show a non-linear decrease in the electrical efficiency as the solar irradiance increased. From $250 \mathrm{~W} / \mathrm{m}^{2}$ to $450 \mathrm{~W} / \mathrm{m}^{2}$ there is a $1.2 \%$ reduction in efficiency in cooled operation and $0.6 \%$ reduction in uncooled operation. Also, from $450 \mathrm{~W} / \mathrm{m}^{2}$ to $650 \mathrm{~W} / \mathrm{m}^{2}$ there is a $0.6 \%$ reduction in efficiency in cooled operation and $0.5 \%$ reduction in uncooled operation. As seen in Fig. 7 when the PV surface temperature increased, the electrical efficiency decreased. Thus, it is expected that the electrical efficiency decrease with increasing irradiance despite the linear increase in power output with irradiance shown in Fig. 10. This effect was also reported in the modelling work of Obalanlege et al. [23].

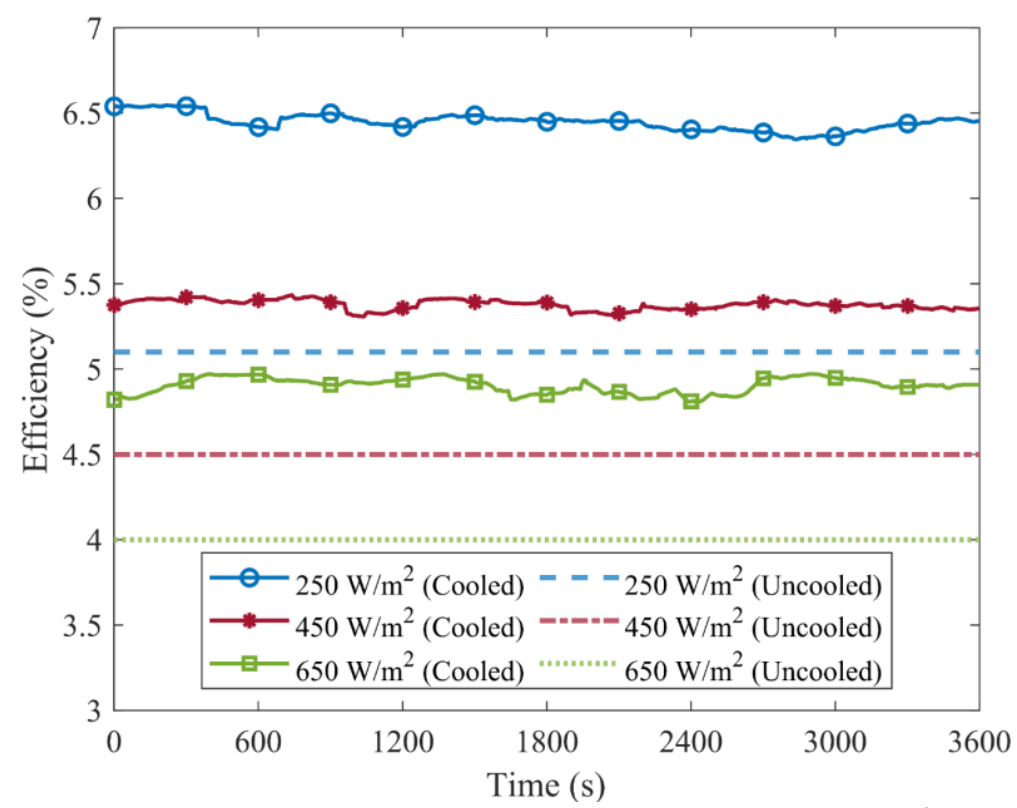

Fig. 11. PV electrical efficiency for different irradiances with $\dot{V}=17.3 \mathrm{l} / \mathrm{min}$ and $V=75$ litres.

Fig. 12 represents the heat output from the condenser of the heat pump, calculated using Eq. (3) in Table 2. For $650 \mathrm{~W} / \mathrm{m}^{2}$ irradiance, the highest heat output peaks at $\sim 8 \mathrm{~kW}$, while $450 \mathrm{~W} / \mathrm{m}^{2}$ and $250 \mathrm{~W} / \mathrm{m}^{2}$ cases had peak heat outputs about $7.5 \mathrm{~kW}$ and $7 \mathrm{~kW}$, respectively. This is due to greater amount of heat being absorbed by the PVT module and transported to the PVT water tank, which is actually the source of heat input to the heat pump.

An interesting observation in Fig. 12 is that in periods when the heat pump stops, the heat output of the condenser is negative for the $250 \mathrm{~W} / \mathrm{m}^{2}$ irradiance. Negative heat output means that heat is absorbed from the user loop and is given to the PVT water tank. This occurs, because the thermal expansion valve in the heat pump is mechanical. Thus, when the compressor shuts down, the valve is still operating, allowing the hot high-pressure refrigerant into the cooler low-pressure side. This causes the high-pressure side to drop in pressure and cool to a temperature lower than the water flowing through the condenser heat exchanger. This reversed temperature difference causes heat to transfer from the water to the refrigerant. The condenser heat output, calculated using Eq. (3) in Table 2, becomes negative as the temperature difference between the water flowing through the condenser 
heat exchanger is reversed. The increased pressure on the low-pressure side causes the refrigerant to increase in temperature beyond the temperature of the water passing through the evaporator. This causes heat to be transferred from the refrigerant to the water. This phenomenon is also seen in the 2012 EA Technology report for the Department of Energy and Climate Change (DECC) [30]. This may be avoided using a solenoid valve that prevents the refrigerant migration whenever the heat pump is off or the use of an electronic expansion valve can be used to prevent this occurring. The effects of short cycling could also be mitigated using an inverter controlled (variable speed) compressor in the heat pump. This would provide control over the work done by the system dependent on the heat available thereby avoiding short cycling conditions.

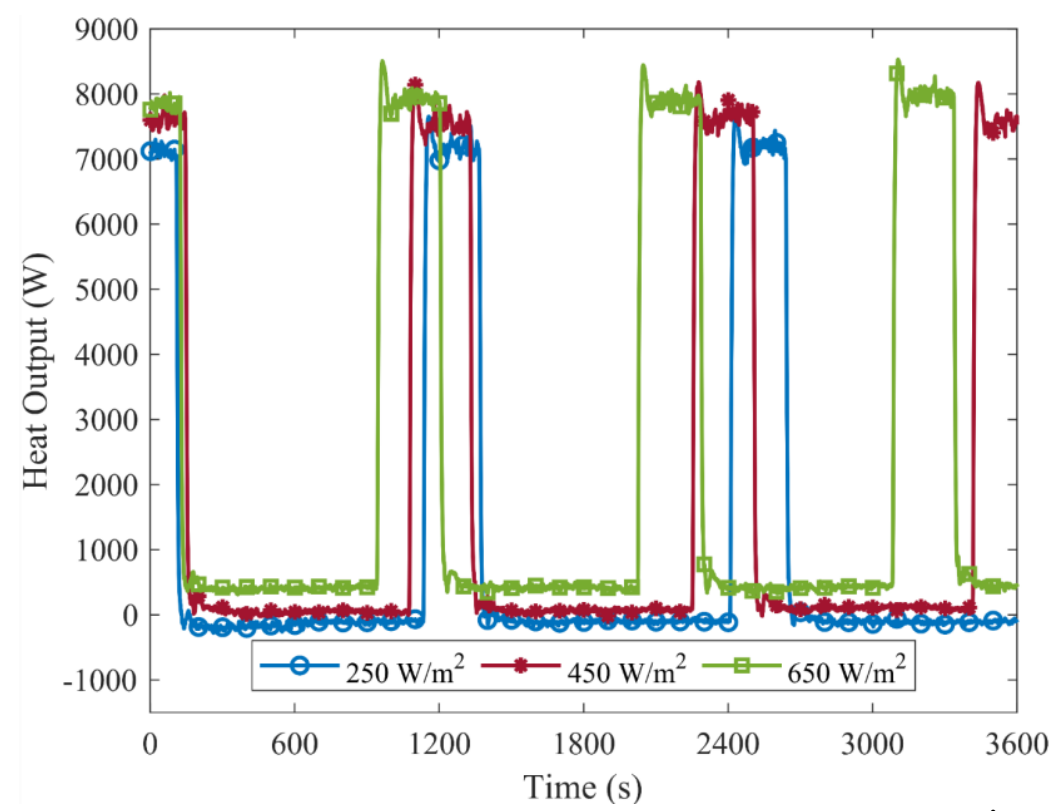

Fig. 12. Heat output from Heat pump for different irradiances with $\dot{V}=17.31 / \mathrm{min}$ and $V=75$ litres.

Table 4 shows the total condenser heat output, calculated using Eq. (4) in Table 2, for the different water flow rates through the PVT module. The total heat output of the heat pump at $650 \mathrm{~W} / \mathrm{m}^{2}$ is more than twice that of the $250 \mathrm{~W} / \mathrm{m}^{2}$ case at $8340 \mathrm{~kJ}$ and $3814 \mathrm{~kJ}$ respectively. This is mainly due to the $650 \mathrm{~W} / \mathrm{m}^{2}$ case having higher heat output peaks as indicated in Fig. 12 and the increase in cycling frequency, allowing more compressor on time than the $250 \mathrm{~W} / \mathrm{m}^{2}$ case.

Table 4: Total heat output for different irradiances

\begin{tabular}{cc}
\hline Irradiance $\left(\mathrm{W} / \mathbf{m}^{\mathbf{2}}\right)$ & $\begin{array}{c}\text { Total Condenser } \\
\text { Heat Output }(\mathbf{k J})\end{array}$ \\
\hline $\mathbf{2 5 0}$ & 3814 \\
$\mathbf{4 5 0}$ & 6566 \\
$\mathbf{6 5 0}$ & 8340 \\
\hline
\end{tabular}

Fig. 13 represents the instantaneous coefficient of performance (COP) of the heat pump during the operation of the IEPVT/HP system calculated using Eq. (6) in Table 2. For solar 
irradiances of $650 \mathrm{~W} / \mathrm{m}^{2}, 450 \mathrm{~W} / \mathrm{m}^{2}$ and $250 \mathrm{~W} / \mathrm{m}^{2}$, COP values of $6.5,6.1$ and 5.5 , respectively are achieved. This only occurs when the heat pump is working. When the heat pump shuts off, the COP drops drastically. It is also seen in Fig. 13 that as the irradiance increased, the cycling frequency of the heat pump increased. As previously stated, this is because the temperature in the PVT water tank rises faster at high irradiances, allowing the heat pump to restart in a shorter amount of time at higher irradiances.

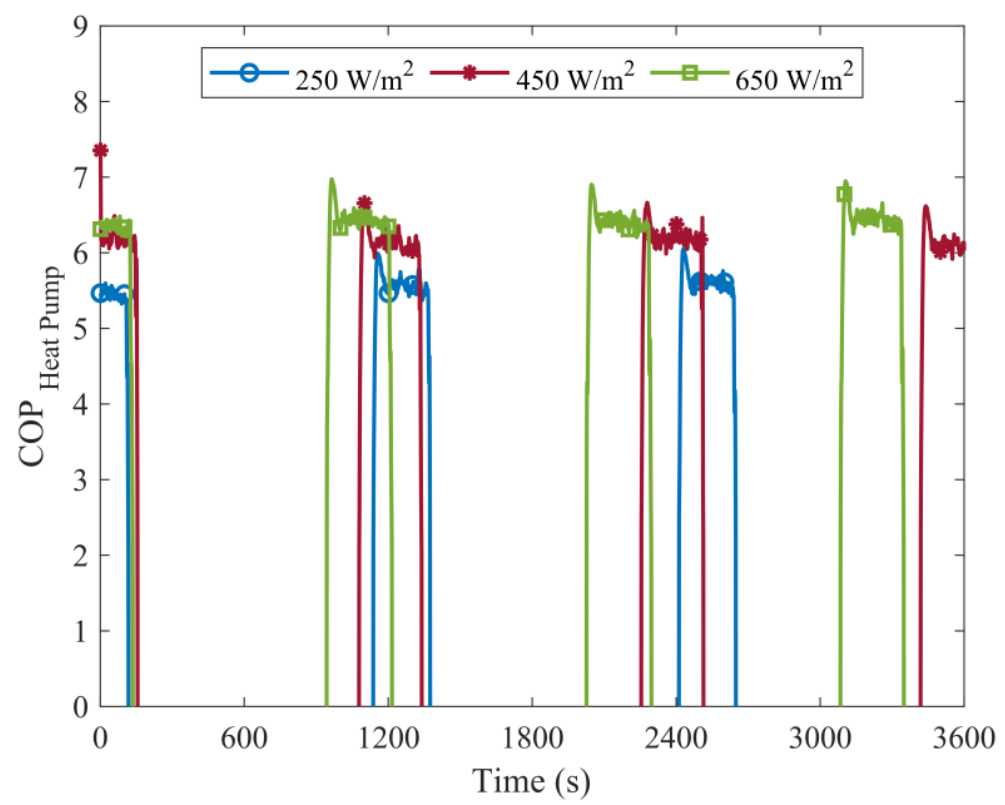

Fig. 13. Heat pump instantaneous COP for different irradiances with $\dot{V}=17.3 \mathrm{l} / \mathrm{min}$ and $V=75$ litres.

Fig. 14 represents the instantaneous coefficient of performance (COP) of the entire IEPVT/HP system, calculated using Eq. (7) in Table 2. The IEPVT/HP system COP is very similar to the heat pump COP in Fig. 13. However, this COP accounts for the work of the radiator fan and water pumps in the system. This account for all the work put into the system in the denominator for the calculation of the COP, thus causing the COP value of the system to scale down in comparison to Fig. 13. It should be noted that the IEPVT/HP system COP also includes the electrical power produced by the PV panel in its numerator, as it is energy generated by the system. However, the amount of electricity produced in this single panel system was comparatively small to the heat pump and water pump power consumptions. 


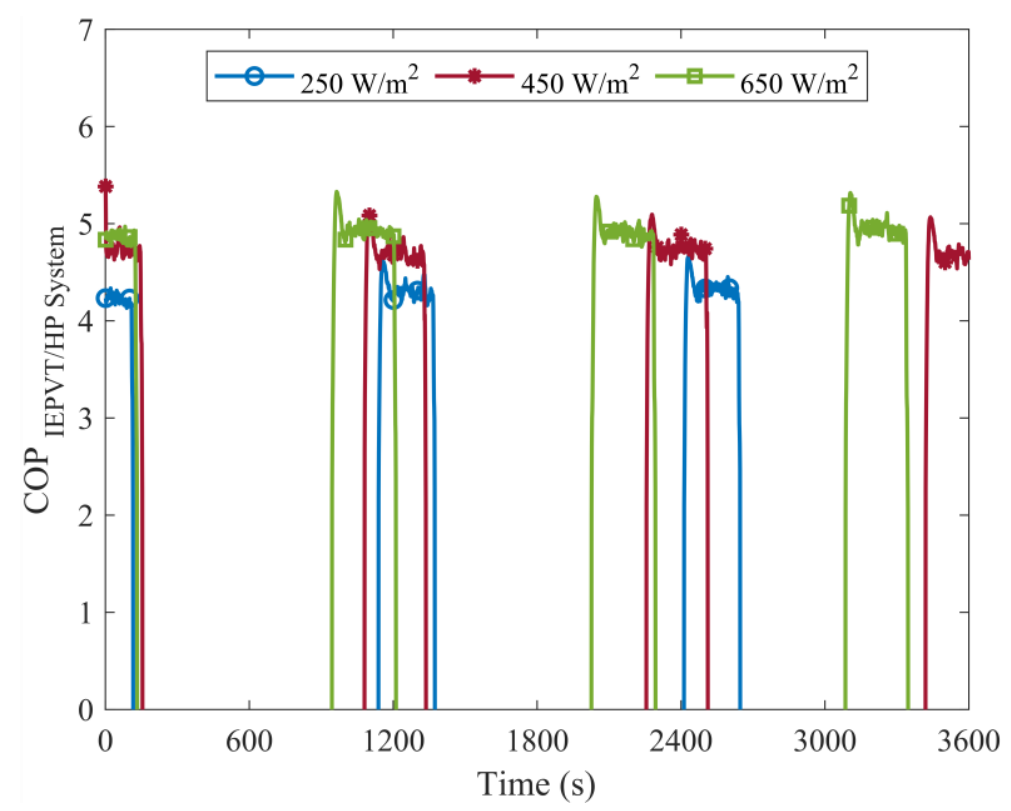

Fig. 14. IEPVT/HP system instantaneous COP for different irradiances with $\dot{V}=17.3 \mathrm{l} / \mathrm{min}$ and $V=75$ litres.

\subsection{Water Flow Rate}

The results given in this subsection studies the IEPVT/HP system over one hour operation with different volumetric flow rates through the PVT module. The flow rates used were 7.3 $1 / \mathrm{min}, 13.2 \mathrm{l} / \mathrm{min}$ and $17.3 \mathrm{l} / \mathrm{min}$. In these experimental tests, the irradiance exposure $(G)$ was kept at $450 \mathrm{~W} / \mathrm{m}^{2}$ and the water volume $(V)$ in the PVT water tank was kept at 75 litres. Fig. 15 shows the change in PV surface temperature for different water flow rates through the PVT module. The broken line represents the uncooled temperature of the PV surface at $450 \mathrm{~W} / \mathrm{m}^{2}$, for reference.

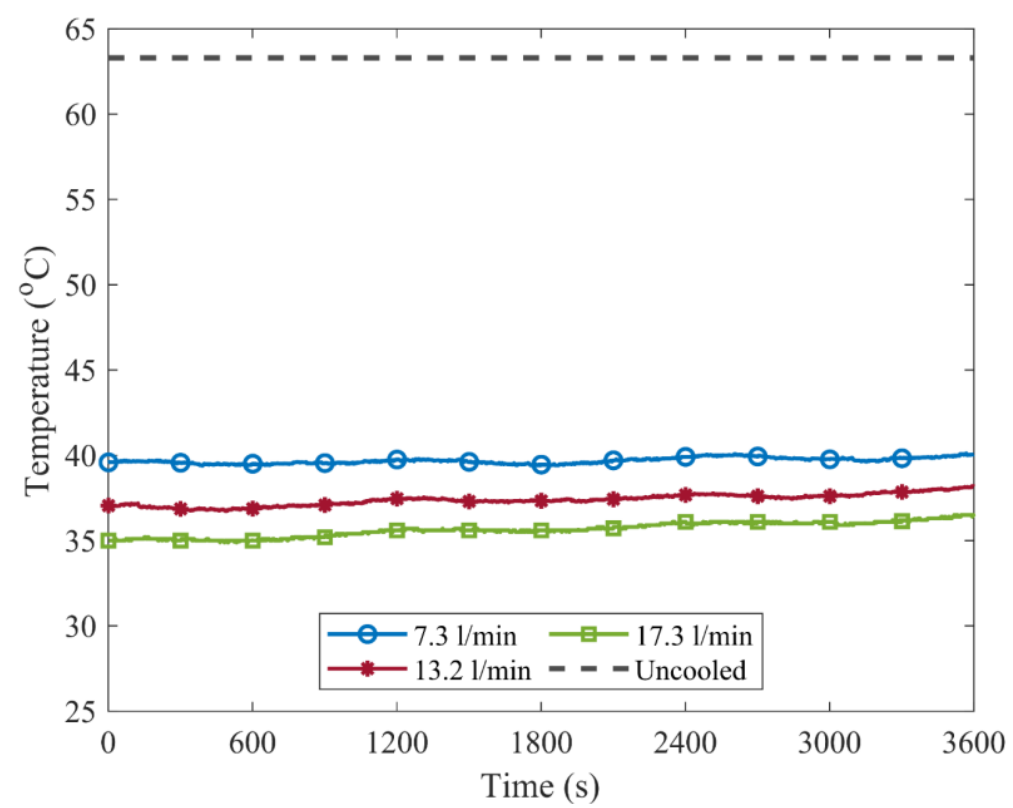

Fig. 15. PV surface temperature for different volumetric flow rates with $G=450 \mathrm{~W} / \mathrm{m}^{2}$ and $V=75$ litres. 
As the water flow rate increased from $7.31 / \mathrm{min}$ to $17.3 \mathrm{l} / \mathrm{min}$, the PV surface temperature decreased from $40^{\circ} \mathrm{C}$ to $35^{\circ} \mathrm{C}$. The temperature of the $\mathrm{PV}$ decreased by $\sim 3^{\circ} \mathrm{C}$ as the flow rate was increased by $5.9 \mathrm{l} / \mathrm{min}$ from $7.3 \mathrm{l} / \mathrm{min}$ to $13.2 \mathrm{l} / \mathrm{min}$. When the flow rate was increased by a further $5.1 \mathrm{l} / \mathrm{min}$ from $13.2 \mathrm{l} / \mathrm{min}$ to $17.3 \mathrm{l} / \mathrm{min}$, the PV surface temperature decreased by a further $\sim 2^{\circ} \mathrm{C}$. This is because increasing the flow rate increased the heat transfer between the PVT module and the water flowing through the PVT.

Fig. 16 shows the inlet and exit temperature of the water flowing through the PVT module in broken and solid lines respectively. The temperature difference experienced by the 7.3 $1 /$ min case was greater than the temperature difference experienced by the $17.31 / \mathrm{min}$ case with the former having a temperature difference of $\sim 1^{\circ} \mathrm{C}$ and the latter having $\sim 0.3^{\circ} \mathrm{C}$. Though higher flow rates led to greater heat transfer, a lower water flow rate increased the residence time of the fluid in the PVT module. This allows the water more time to heat up thus achieving a higher exit temperature.

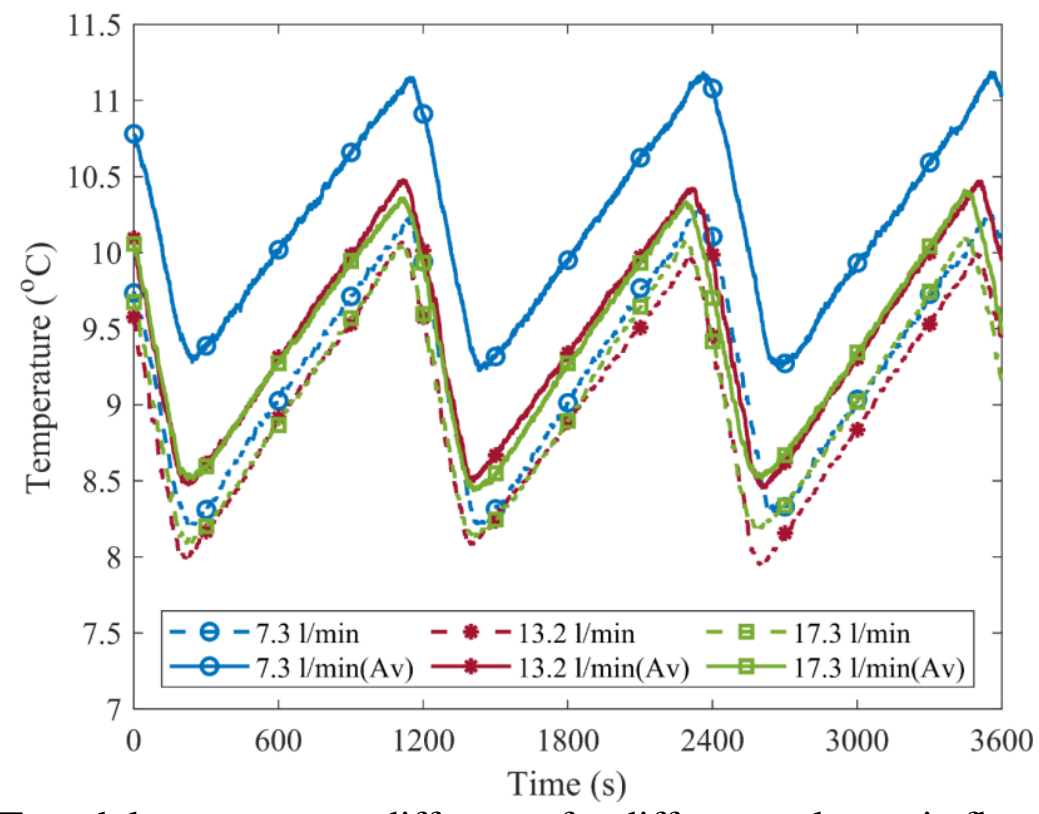

Fig. 16. PVT module temperature difference for different volumetric flow rates with $G=450 \mathrm{~W} / \mathrm{m}^{2}$ and $V=75$ litres.

Fig. 17 shows the change in PVT water tank temperature. There was very little difference in the temperature of the PVT water tank with a change in flow rate. This shows that the water flow rate has negligible influence on the PVT water tank temperature. However, Fig. 17 also shows that increasing the water flow rate in the PVT module, increased the frequency of the cycling of the PVT water tank temperature slightly. 


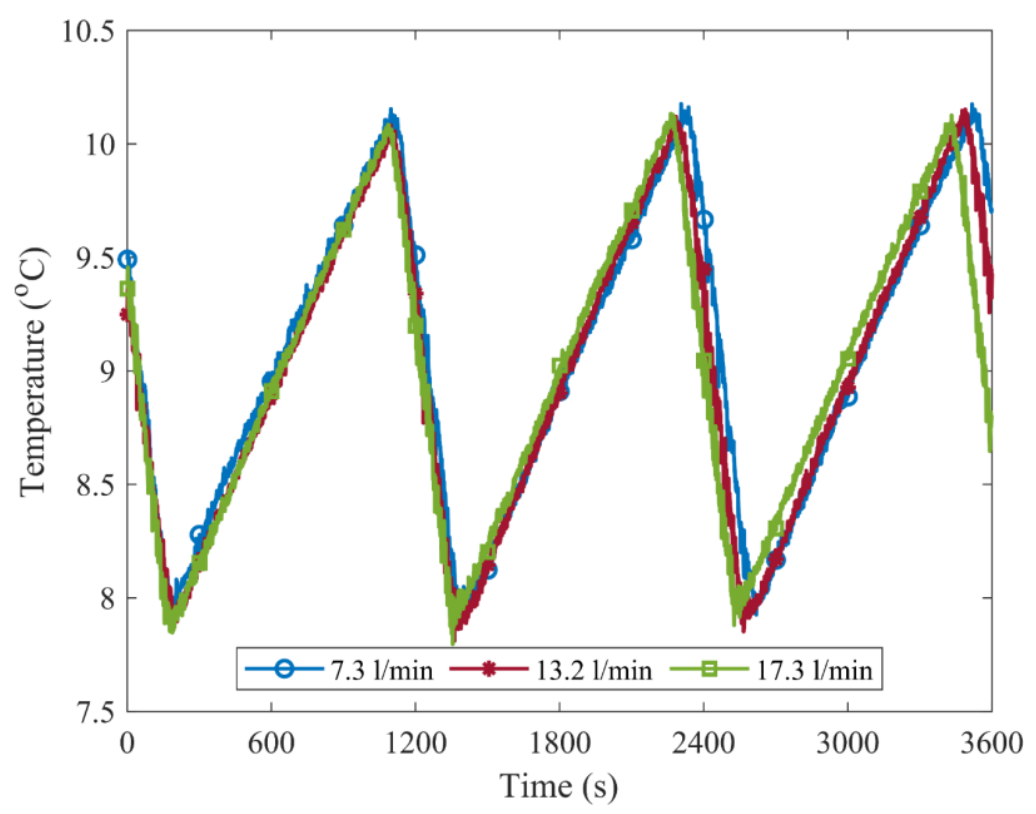

Fig. 17. PVT water tank temperature for different volumetric flow rates with $G=450 \mathrm{~W} / \mathrm{m}^{2}$ and $V=75$ litres.

Fig. 18 represents the electricity production of the PV panel for different water flow rates through the PVT module, calculated using Eq. (1) in Table 2. The $7.31 / \mathrm{min}$ case produced the lowest electrical output, averaging $28.5 \mathrm{~W}$, while the $17.3 \mathrm{l} / \mathrm{min}$ case produced the highest electrical output, averaging $30.3 \mathrm{~W}$. Since the irradiance was the same for all the cases, this demonstrates that increasing the water flow rate through the PVT module increased the PV electrical output.

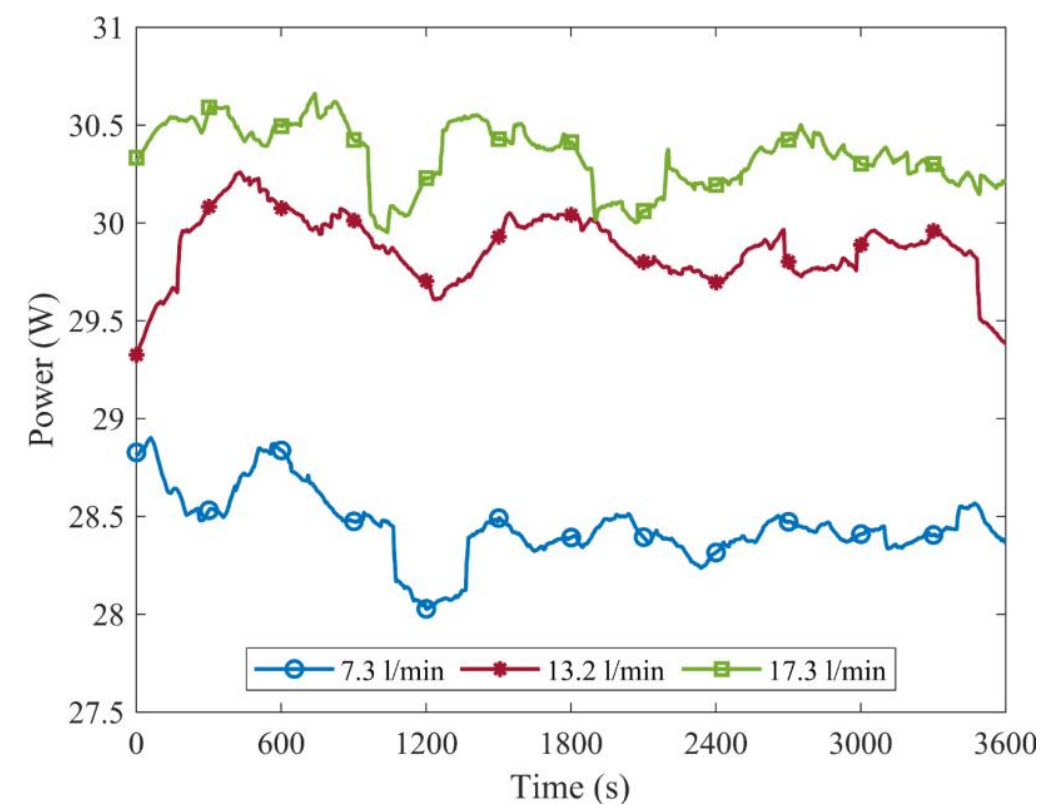

Fig. 18. PV electricity production for different volumetric flow rates with $G=450 \mathrm{~W} / \mathrm{m}^{2}$ and $V=75$ litres.

Fig. 19 graphs the electrical efficiency of the PV panel for different water flow rates through the PVT module calculated using Eq. (5) in Table 2. The broken line represents the electrical efficiency of the uncooled PV panel. The electrical efficiency follows the same trend as the electrical output given in Fig. 18. This shows that changing the flow rate through 
the PVT module affects the electrical efficiency and electricity production by increasing or decreasing both measurements. This in contrast to what was seen in section 4.1 (Fig. 10 and Fig. 11), in which increasing the irradiance, increased the electricity production but decreased the electrical efficiency.

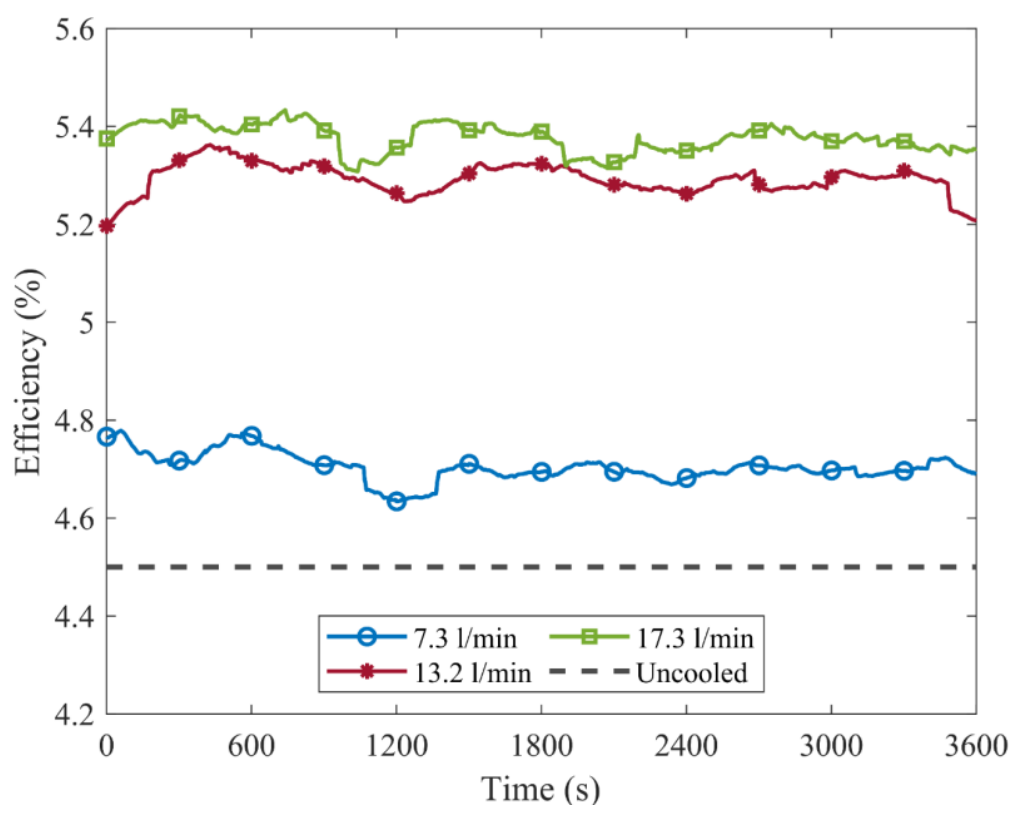

Fig. 19. PV electrical efficiency for different volumetric flow rates with $G=450 \mathrm{~W} / \mathrm{m}^{2}$ and $V=75$ litres.

Fig. 20 shows the instantaneous coefficient of performance (COP) of the heat pump with varying water flow rates through the PVT module, calculated using Eq. (6) in Table 2. The figure shows there was a small but noticeable shift in heat pump switch -on and -off times. The highest flow rate case $(17.3 \mathrm{l} / \mathrm{min})$ tends to switch-on earlier than the lowest flow rate case $(7.3 \mathrm{l} / \mathrm{min})$. Though the flow rate through the PVT module was not directly linked to the performance of the heat pump [23], it influences the PVT water tank that supplies the heat pump with a source of heat input. As previously discussed, the higher water flow rates, leads to a faster heating the PVT water tank. This causes the heat pump to turn on quicker and thus decreasing the heat pump off time. However, according to Fig. 20, this effect due to the water flow rate was very small. 


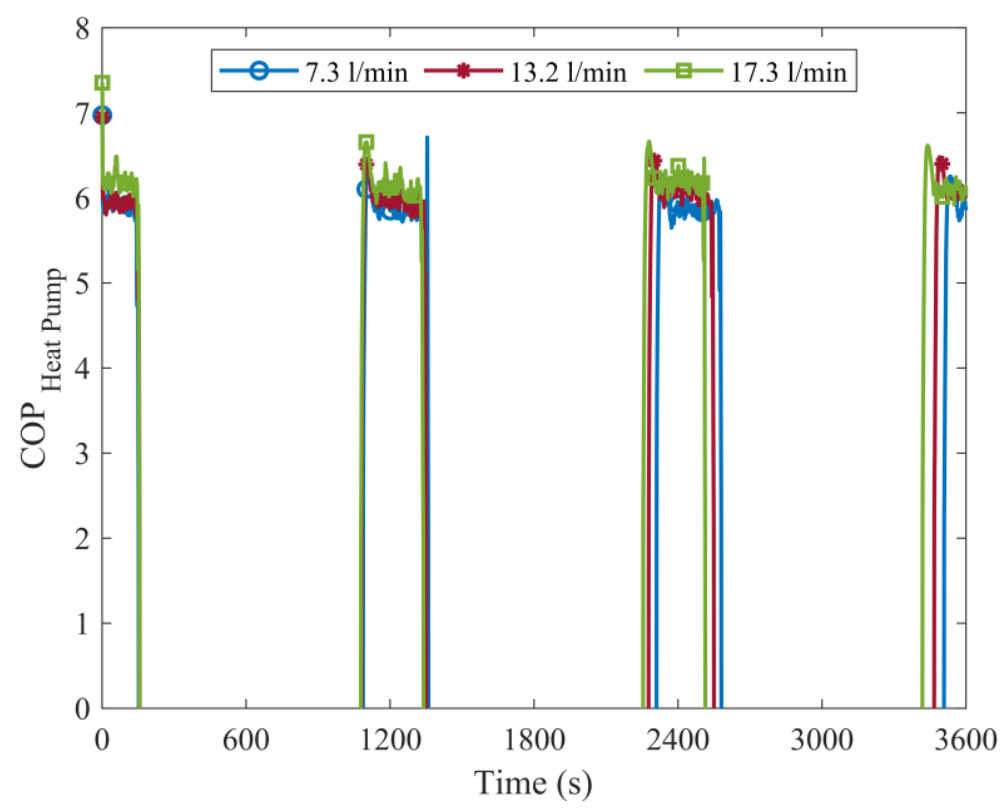

Fig. 20. Heat pump instantaneous COP for different volumetric flow rates with $G=450 \mathrm{~W} / \mathrm{m}^{2}$ and $V=75$ litres.

Fig. 21 graphs the instantaneous coefficient of performance (COP) of the entire IEPVT/HP system, calculated using Eq. (7) in Table 2. The IEPVT/HP instantaneous COP in Fig. 21 is lower than that of the heat pump COP (Fig. 20) during operation. This is due to the previously discussed inclusion of the power consumption of the water pumps and radiator fan as well as the electricity generated by the cooled PV panel in the calculation of the COP. There is no discernible difference in the instantaneous COP during operation. This lack of difference in the instantaneous COP during operation was also reported in the mathematical modelling of Obalanlege et al. [23].

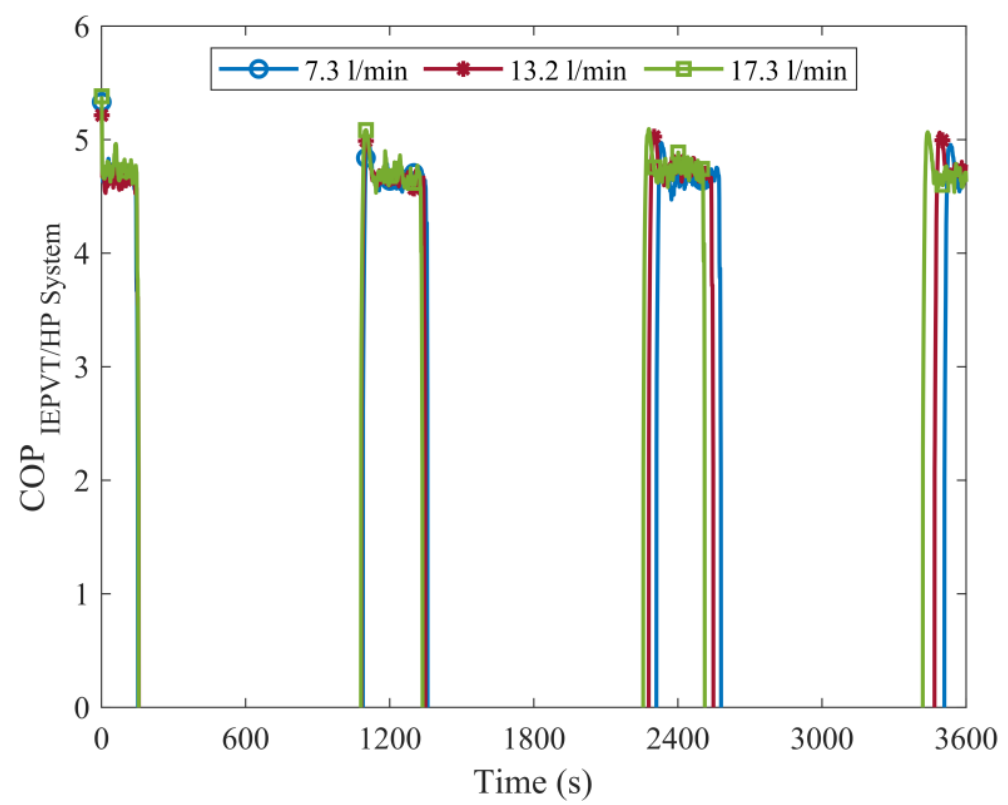

Fig. 21. IEPVT/HP system instantaneous COP for different volumetric flow rates with $G=450 \mathrm{~W} / \mathrm{m}^{2}$ and $V=75$ litres. 
Table 5 shows the total condenser heat output, calculated using Eq. (4) in Table 2, for the different water flow rates through the PVT module. Increasing the water flow rate from 7.3 $1 / \mathrm{min}$ to $17.3 \mathrm{l} / \mathrm{min}$ led to a $544 \mathrm{~kJ}$ increase in total heat production over the one-hour operation time. The largest contributor to the heat output increase was the increase in cycle frequency occurring for higher water flow rate, an effect that was also seen in Table 4.

Table 5: Total heat output for different water flow rates

\begin{tabular}{cc}
\hline $\begin{array}{c}\text { Water Flow rate } \\
(\mathbf{l} / \mathbf{m i n})\end{array}$ & $\begin{array}{c}\text { Total Condenser } \\
\text { Heat Output (kJ) }\end{array}$ \\
\hline $\mathbf{7 . 3}$ & 6045 \\
$\mathbf{1 3 . 2}$ & 6395 \\
$\mathbf{1 7 . 3}$ & 6589 \\
\hline
\end{tabular}

\subsection{PVT Water Tank Volume}

The results given in this subsection analyses the IEPVT/HP system for different volumes of water in the PVT water tank. The volumes of water used were 45 litres, 65 litres and 75 litres. In these experimental tests, the irradiance exposure $(G)$ was kept at $450 \mathrm{~W} / \mathrm{m}^{2}$ and the water volumetric flow rate $(\dot{V})$ through the PVT module was kept at $13.2 \mathrm{l} / \mathrm{min}$. Fig. 22 represents the temperature of the PV panel when the IEPVT/HP system operates with varying volumes of water in the PVT water tank. The 60 -litre case was $3^{\circ} \mathrm{C}$ hotter than the 75 -litres case, while the 45 -litre case was $2^{\circ} \mathrm{C}$ hotter than the 60 -litre case. The temperature difference between the cases stay constant over the hour of operation. This shows that larger PVT water tanks allow for more effective cooling of the PV panels.

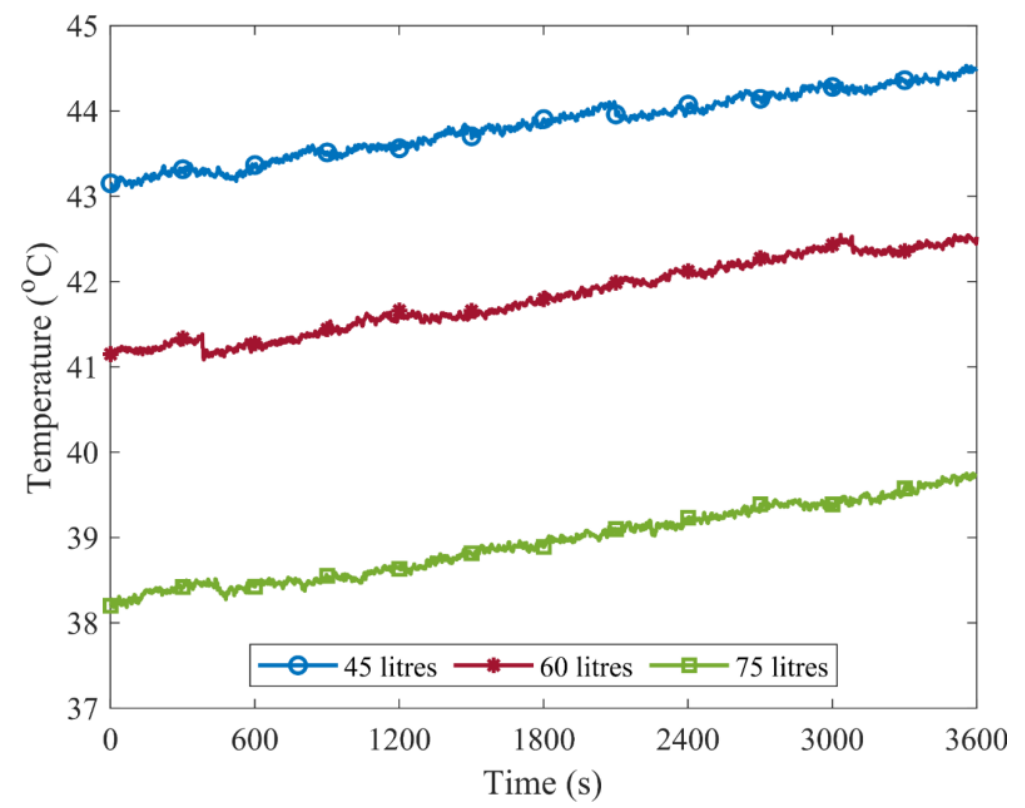

Fig. 22. PV surface temperature for different PVT water tank volumes with

$$
G=450 \mathrm{~W} / \mathrm{m}^{2} \text { and } \dot{V}=13.2 \mathrm{l} / \mathrm{min} \text {. }
$$

Fig. 23 and Fig. 24 show the inlet and exit temperature of the water in the PVT, and the PVT water tank temperature, respectively. The 45-litre case was able to complete six heating 
and cooling cycles in one hour, while the 60-litre case was able to complete 4 cycles and the 75-litre case was able complete 3 cycles. The heat pump in the IEPVT/HP system was programmed to shut off when the water entering the evaporator was under $8^{\circ} \mathrm{C}$ and restart when the water entering the evaporator was over $10^{\circ} \mathrm{C}$. These plots show that smaller volumes heat and cool much faster than larger volumes, resulting in higher number of short cycling in the system. This means that larger PVT water tank volumes can be used to damp the heating and cooling cycling and limit the number of times the heat pump has to switch on and off. Additionally, Fig. 24 shows that the water temperatures in the PVT and the tank have narrower range of variation for the smallest volume (45 litres) in comparison to the largest volume (75 litres). The 45 -litre case had a temperature change of $1^{\circ} \mathrm{C}$ (from $9^{\circ} \mathrm{C}$ to $10^{\circ} \mathrm{C}$ ), the 60 -litre case had a temperature change of $1.5^{\circ} \mathrm{C}$, and the 75 -litre case had a temperature change of $2^{\circ} \mathrm{C}$. This result is counterintuitive as the cycles are dictated by the temperature of the water entering the heat pump evaporator from the PVT water tank. This means the water temperature change of the PVT module should be approximately $2^{\circ} \mathrm{C}$ as the tank temperature changes between $8^{\circ} \mathrm{C}$ and $10^{\circ} \mathrm{C}$. However, as the PVT water tank temperature (given in Fig. 24) was measured at one point between the PVT module inlet pipe and the evaporator inlet pipe, it indicates a stratification of temperature within the water tank. The 45-litre tank does not allow enough convection to take place to equalise the tank temperature between the PVT module and the heat pump evaporator. As the PVT water tank size increased, the cycles decrease allowing the water tank to better equalise the tank temperature and thus the measured temperature ranges increase towards that of the programmed temperature range.

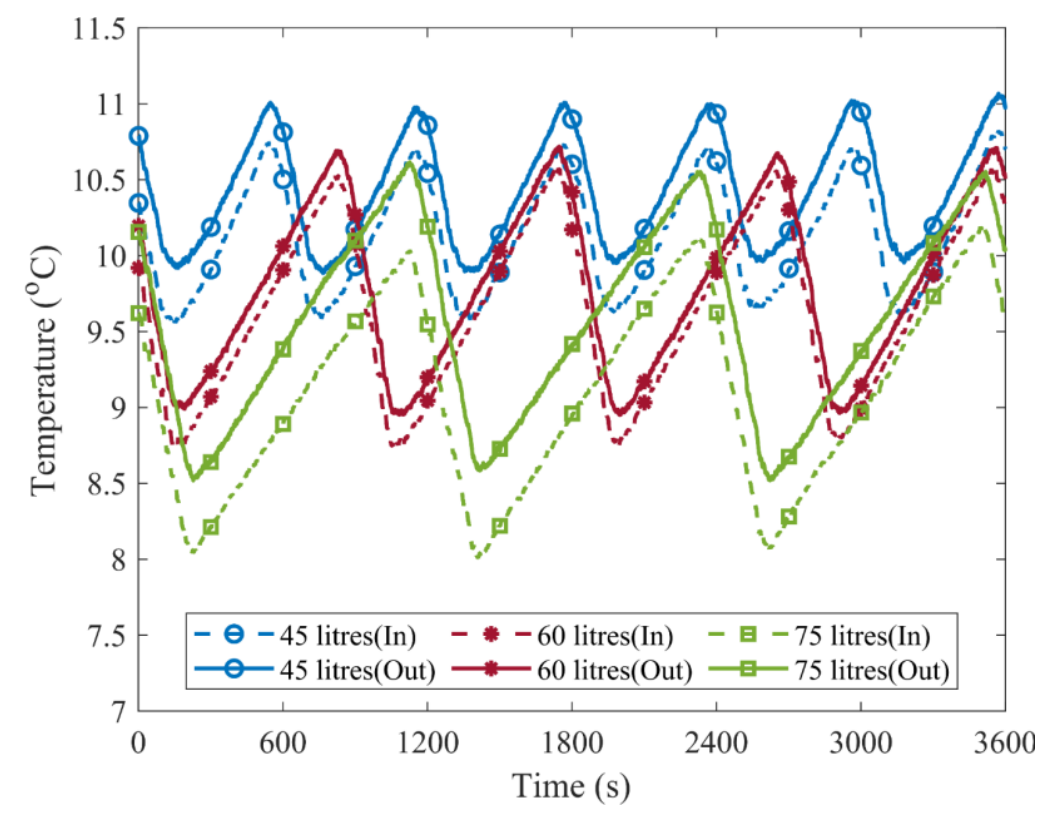

Fig. 23. PVT module temperature difference for different PVT water tank volumes with $G=450 \mathrm{~W} / \mathrm{m}^{2}$ and $\dot{V}=13.2 \mathrm{l} / \mathrm{min}$. 


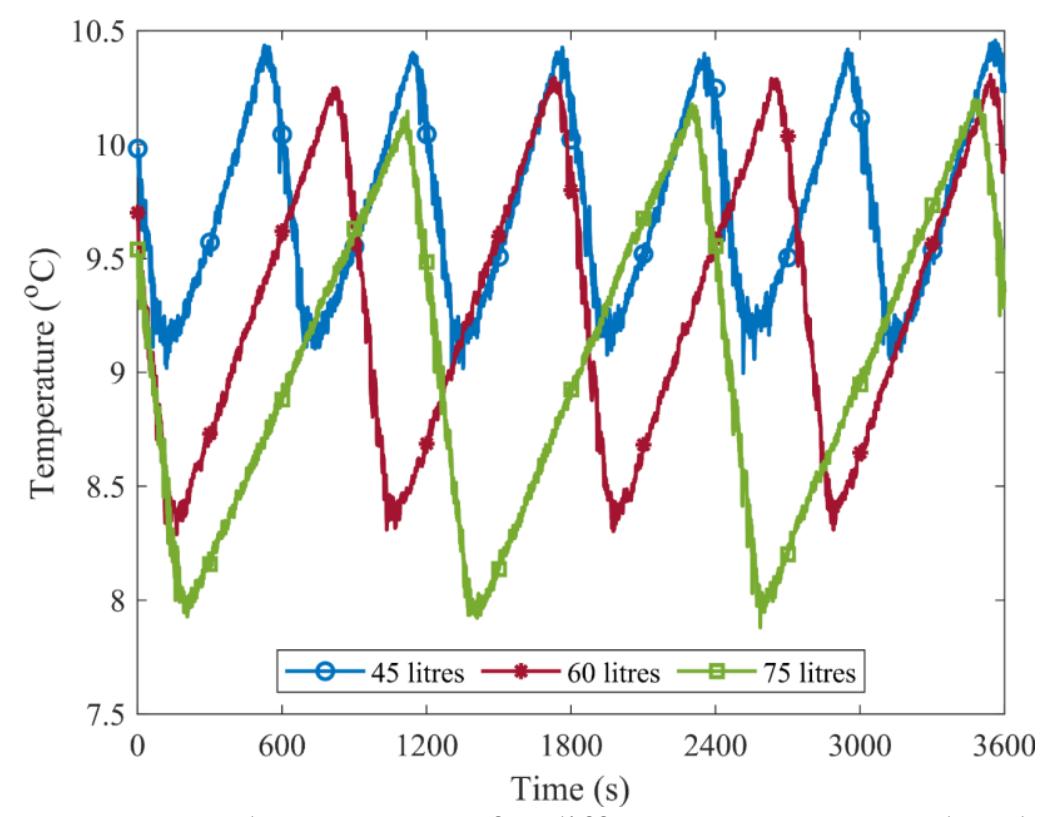

Fig. 24. PVT water tank temperature for different PVT water tank volumes with $G=450 \mathrm{~W} / \mathrm{m}^{2}$ and $\dot{V}=13.2 \mathrm{l} / \mathrm{min}$.

Fig. 25 and Fig. 26 show the electricity production and the electrical efficiency calculated using Eq. (1) and Eq. (5), respectively in Table 2 for different PVT water tank volumes over the operation of the system. In Fig. 26, the broken line represents the uncooled PV panel electrical efficiency for reference. It was seen that as the tank size increased from 45 litres to 75 litres, the electricity production increased from $27.25 \mathrm{~W}$ (on average) to $30.75 \mathrm{~W}$. Additionally, the electrical efficiency increased from $5.1 \%$ to $5.7 \%$. As previously discussed, both the electrical production and electrical efficiency are influenced by the PV panel surface temperature. It was experimentally seen in Fig. 22 that as PVT water tank volume increased the PV surface temperature decreased. The decrease in the PV surface temperature leads to the increase in the electrical production of approximately $1.75 \mathrm{~W}$ for each 15 litres increase in PVT water tank volume. This correlates to a $0.3 \%$ increase in electrical efficiency per 15 litres volume increase. 


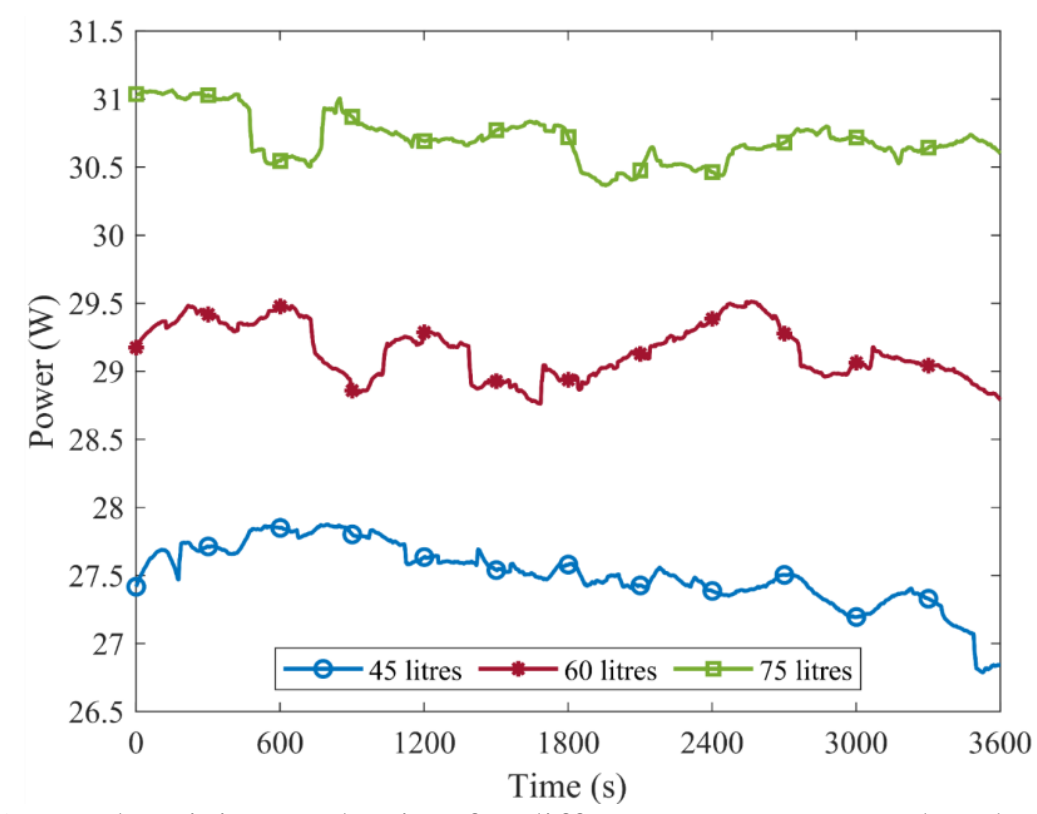

Fig. 25. PV electricity production for different PVT water tank volumes with $G=450 \mathrm{~W} / \mathrm{m}^{2}$ and $\dot{V}=13.2 \mathrm{l} / \mathrm{min}$.

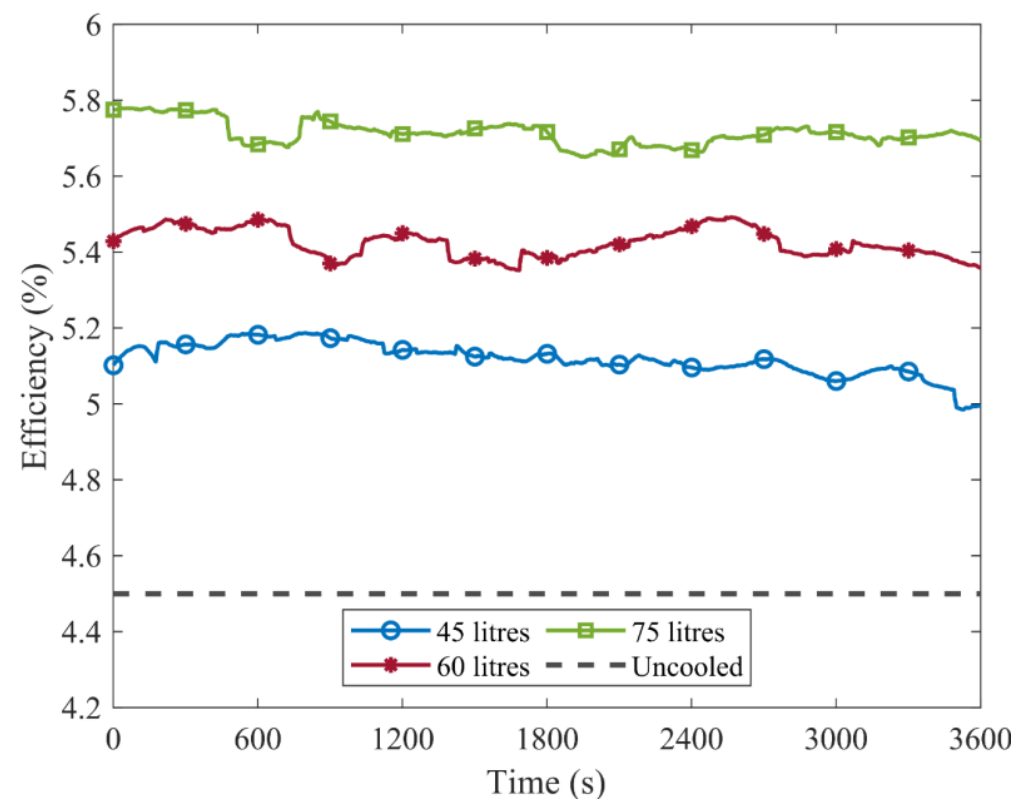

Fig. 26. PV electrical efficiency for different PVT water tank volumes with

$$
G=450 \mathrm{~W} / \mathrm{m}^{2} \text { and } \dot{V}=13.2 \mathrm{l} / \mathrm{min} \text {. }
$$

Fig. 27 shows the instantaneous coefficient of performance (COP) of the heat pump calculated using Eq. (6) in Table 2 for various PVT water tank volumes. It is seen that when the COP of the heat pump decreased as the tank volume decreased. The average COP of the heat pump for the 75-litre case was about 5.9, with the COP of 5.5 for the 45 -litre case. The heat pump short cycles with higher frequency as the tank volume decreased. The 45-litre case achieves 6 cycles in one-hour operation time, while the 75-litre case achieves 3 cycles. The figure further shows that the ON time of the heat pump spent in each cycle decreased as the tank volume decreased. The time it takes for a single heating and cooling cycle was 20 minutes, 14.5 minutes and 7.5 minutes for the 75, 60 and 45 litres tank volumes, 
respectively. The switched-on time for these cases were 5 minutes, 3.3 minutes and 3 minutes this correlates to $25 \%, 23 \%$ and $40 \%$ switched-on time during each cycle respectively.

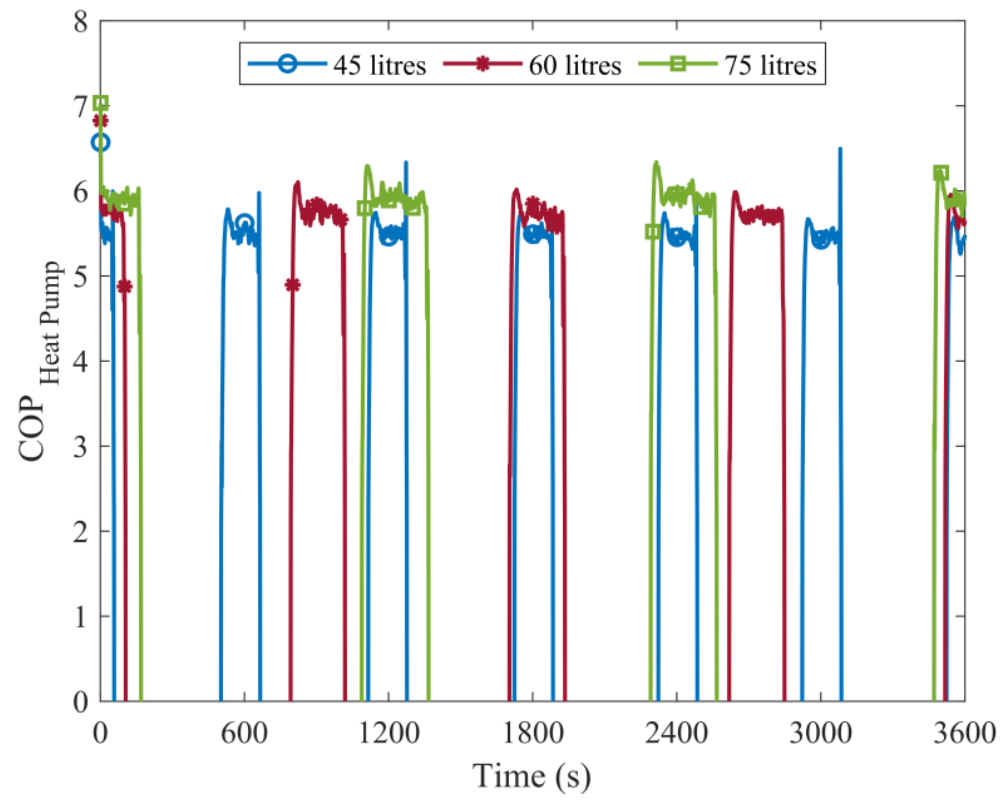

Fig. 27. Heat pump instantaneous COP for different PVT water tank volumes with $G=450 \mathrm{~W} / \mathrm{m}^{2}$ and $\dot{V}=13.2 \mathrm{l} / \mathrm{min}$.

Fig. 28 shows the instantaneous coefficient of performance (COP) of the entire IEPVT/HP system, calculated using Eq. (7) in Table 2, for various PVT water tank volumes over the operation of the system. The trend in the instantaneous COP of the IEPVT/HP system when compared to the PVT water tank volume is similar to that of Fig. 27. The system's instantaneous COP takes into account the energy consumption of the water pumps and radiator fan as well as the electricity production of the PV panel. This scales down the COP values as the ratio of energy generated to energy consumed decreased.

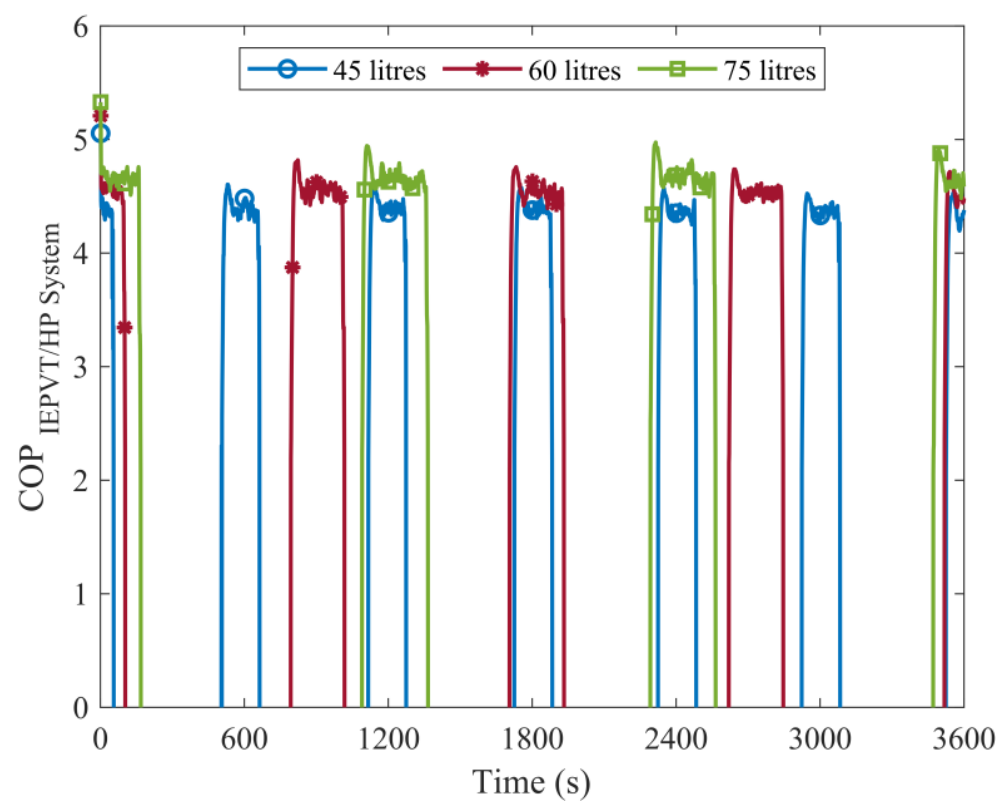


Fig. 28. IEPVT/HP system instantaneous COP for different PVT water tank volumes with $G=450 \mathrm{~W} / \mathrm{m}^{2}$ and $\dot{V}=13.2 \mathrm{l} / \mathrm{min}$.

Table 6 shows the total condenser heat output for different water flow rates through the PVT module. The lowest total heat output was given by the 75 -litre tank volume at $7041 \mathrm{~kJ}$, while the smaller tank volume, 45 litres yields the highest total heat output of $7636 \mathrm{~kJ}$. The $595 \mathrm{~kJ}$ difference in these values was due to the drastic change in cycle frequency between the 75 -litre volume ( 3 cycle/hour) and 45 -litre volume (6 cycles/hour). The 75-litre case also has a $164 \mathrm{~kJ}$ lower total heat output than the 60 -litre case. This may be due to the compressor ON time being longer on the 75-litre case than the 60-litre case and thus offsetting the decrease due to short-cycle frequency. Hence, the 45-litre case achieves a highest total heat output than the other cases. It is important to note that though the 45-litre case has the highest output, the short cycle condition was much more severe. The 45-litre case has a frequency 6 cycles/hour, increasing possible compressor damage to constant switching ON and OFF and increasing compressor unreliability [27].

Table 6: Total heat output for different PVT water tank volumes

\begin{tabular}{cc}
\hline $\begin{array}{c}\text { PVT Water Tank } \\
\text { Volume (litres) }\end{array}$ & $\begin{array}{c}\text { Total Condenser } \\
\text { Heat Out }(\mathbf{k J})\end{array}$ \\
\hline $\mathbf{4 5}$ & 7635 \\
$\mathbf{6 0}$ & 7205 \\
$\mathbf{7 5}$ & 7041 \\
\hline
\end{tabular}

\section{Conclusions}

In this work, the performance characteristics of an indirect expansion photovoltaicthermal heat pump (IEPVT/HP) system was experimentally analysed under the shortcycling conditions. The study focused on the impact of solar irradiance, water flow rate in the photovoltaic-thermal module and the water tank volume on the system's performance. The solar irradiance represented a parameter that is dictated by the environment and location of the system. The photovoltaic-thermal water tank volume represented a parameter important to the design considerations of the indirect expansion photovoltaic-thermal heat pump system. The water flow rate in the photovoltaic-thermal module represented a parameter that is programmable and changeable after the installation and implementation of the system. The experimental results provided evidence for the viability and successful operation of the system. The experiment further highlighted the impact of the short cycling on the system operation. The main findings of this work are as follows:

- The indirect expansion photovoltaic-thermal heat pump (IEPVT/HP) system successfully cools the PV surface by as much as $33^{\circ} \mathrm{C}$ under $650 \mathrm{~W} / \mathrm{m}^{2}$ irradiance. This leads to a measured electrical efficiency saving of $0.7 \%$, corresponding to a $17.5 \%$ increase in the electrical power output. The heat pump coefficient of performance (COP) varies between 5 and 7 for different irradiances. The total indirect expansion photovoltaic-thermal heat pump (IEPVT/HP) system 
coefficient of performance also reaches between 4 and 5 during heat pump compressor operation.

- Increasing the solar irradiance from $250 \mathrm{~W} / \mathrm{m}^{2}$ to $650 \mathrm{~W} / \mathrm{m}^{2}$ found to double the electrical power output. While the electrical efficiency found to be reduced by increasing the solar irradiation (from $6.5 \%$, for $250 \mathrm{~W} / \mathrm{m}^{2}$ case, to $4.7 \%$, for the 650 $\mathrm{W} / \mathrm{m}^{2}$ case). Increasing the solar irradiance also had significant effect on the heat pump coefficient of performance peak values and the rate at which short cycling occurred. This leads to a system heat output of $8340 \mathrm{~kJ}$ at $650 \mathrm{~W} / \mathrm{m}^{2}$ compared to $3814 \mathrm{~kJ}$ at $250 \mathrm{~W} / \mathrm{m}^{2}$.

- For a fixed solar irradiance, changing the photovoltaic-thermal water flow rate does not have significant influence on the system's performance. It was found that the photovoltaic surface temperature decreased by $5^{\circ} \mathrm{C}$ as the flow rate increased from $7.3 \mathrm{l} / \mathrm{min}$ to $17.3 \mathrm{l} / \mathrm{min}$. This effects the electrical output and the electrical efficiency to increase by $2 \mathrm{~W}$ and $0.6 \%$, respectively. Additionally, increasing the photovoltaic-thermal water flow rate increased the frequency of short cycling, indicating that it increased the amount of heat entering the system. The $17.3 \mathrm{l} / \mathrm{min}$ flow rate allows the system to produce $6589 \mathrm{~kJ}$ of heat within the one hour operating time, while the $7.3 \mathrm{l} / \mathrm{min}$ flow rate produced a lower heat output of 6045 $\mathrm{kJ}$.

- Changing the photovoltaic-thermal water tank size (from 45 litres to 75 litres) influences the temperature of the photovoltaic surface with a 45 -litre tank having a PV surface $5^{\circ} \mathrm{C}$ hotter than the 75 -litre tank case. Decreasing the tank volume from 75 litres to 45 litres, leads to a decrease in the electrical output and electrical efficiency of $3.5 \mathrm{~W}$ and $0.7 \%$, respectively. The photovoltaic-thermal water tank volume has a significant effect on the heat pump and indirect expansion photovoltaic-thermal heat pump system coefficient of performance in terms of short cycle frequency. The 45litre, 60-litre and 75-litre cases had a short cycle frequency of 6, 4 and 3 cycles/hour. The 45-litre case also produced the most heat at $7635 \mathrm{~kJ}$, despite it having the highest short cycling frequency, lowest coefficient of performance peaks and shortest heat pump compressor -on times.

\section{Acknowledgements}

This work was supported by the Northern Ireland Department for the Economy and BL Refrigeration \& Air Conditioning Ltd) under the Grant No. R5036MEE.

\section{References}

[1] S. Yilmaz, D. Majcen, M. Heidari, J. Mahmoodi, T. Brosch and M. K. Patel, "Analysis of the impact of energy efficiency labelling and potential changes on electricity demand reduction of white goods using a stock model: The case of Switzerland," Applied Energy, vol. 239, pp. 117-132, 2019.

[2] International Energy Agency (IEA), "Energy Efficiency 2018," IEA Publications, 2018.

[3] D. Marini, "Optimization of HVAC systems for distributed generation as a function of different types 
of heat sources and climatic conditions," Applied Energy, vol. 102, pp. 813-826, 2013.

[4] T. Abergel, J. Dulac and C. Delmastro, "IEA Heating: Tracking Clean Energy Progress," 06062019. [Online]. Available: iea.org/tcep/buildings/heating/. [Accessed 31 October 2019].

[5] A. Eisentraut and A. Brown, "Heating Without Global Warming: Market Developments and Policy Considerations for Renwable Heat," IEA Publishing, 2014.

[6] H. Chen, L. Zhang, P. Jie, Y. Xiong, P. Xu and H. Zhai, "Performance study of heat-pipe solar photovoltaic/thermal heat pump system," Applied Energy, vol. 190, pp. 960-980, 2017.

[7] A. Ramos, I. Guarrancino, A. Mellor, D. Alonso-Álvarez, P. Childs, N. J. Ekins-Daukes and C. N. Markides, "Solar-Thermal and Hybrid Photovoltaic-Thermal Systems for Renewable Heating," Grantham Institute, London, 2017.

[8] P. Dupeyrat, C. Ménézo and S. Fortuin, "Study of the thermal and electrical performances of PVT solar hot water system," Energy and Buildings, vol. 68, pp. 751-755, 2014.

[9] C. Rossi, L. A. Tagliafico, F. Scarpa and V. Bianco, "Experimental and numerical results from hybrid retrofitted photovoltaic panels," Energy Conversion and Management journal, vol. 76, pp. 634-644, 2013.

[10] D. Das, P. Kalita and O. Roy, "Flat plate hybrid photovoltaic- thermal (PV/T) system: A review on design and development," Renewable and Sustainable Energy Reviews, vol. 84, pp. 111-130, 2018.

[11] S. S. Joshi and A. S. Dhoble, "Photovoltaic-Thermal systems (PVT): Technology review and future trends," Renewable and Sustainable Energy Reviews, vol. 92, pp. 848-882, 2018.

[12] S. A. Kalogirou, "Photovoltaic Systems," in Solar Energy Engineering: Processes and Systems, Academic Press, 2014, pp. 481-540.

[13] M. Herrando, C. N. Markides and K. Hellgardt, "A UK-based assessment of hybrid PV and solarthermal systems for domestic heating and power: System performance," Applied Energy, vol. 122, pp. 288-309, 2014.

[14] C. Skidmore, "gov.uk," 27 June 2019. [Online]. Available: gov.uk/government/news/uk-becomes-firstmajor-economy-to-pass-net-zero-emissions-law. [Accessed 31 October 2019].

[15] European Commission, "Paris Agrrement," December 2015. [Online]. Available: ec.europa.eu/clima/policies/international/negotiations/paris_en. [Accessed 31 October 2019].

[16] Department for Business, Energy \& Industrial Strategy, "Evidence Gathering - Low Carbon Heating Technologies: Hybrid Solar Photovoltaic Thermal Panels," Department for Business, Energy \& Industrial Strategy, London, 2016.

[17] International Energy Agency, "CO2 emmisions from fuel combustion," IEA publishing, 2019.

[18] International Energy Agency, "Renewables Information: Overview," IEA Publishing, 2019.

[19] International Energy Agency, "Technology roadmap: Solar heating and Cooling," IEA Publishing, 2012.

[20] J. Cai, Y. Wang and W. Huang, "Numerical simulation and experimental validation of indirect expansion solar-assisted multi-functional heat pump," Renewable Energy, vol. 93, pp. 280-290, 2016.

[21] Q. Wang, Y.-q. Liu, G.-f. Liang, J.-r. Li, S.-f. Sun and G.-m. Chen, "Development and experimental validation of a novel indirect-expansion solar-assisted multifunctional heat pump," Energy and Buildings, vol. 42, no. 2-3, pp. 300-304, 2011.

[22] S. Harrison, "The Potential and Challenges of Solar Boosted Heat Pumps for Domestic Hot Water Heating," in Proceedings of 12th IEA Heat Pump Conference, Rotherdam, 2017.

[23] M. A. Obalanlege, Y. Mahmoudi, R. Douglas, E. Ebrahimnia-Bajestan, J. Davidson and D. Bailie, "Performance assessment of a hybrid photovoltaic-thermal and heat pump system for solar heating and electricity," Renewable Energy, vol. 148, pp. 558-572, 2020.

[24] J. Cai, J. Ji, Y. Wang and W. Huang, "Operation characteristics of a novel dual source mult-functional heat pump system under various working modes," Applied Energy, vol. 194, pp. 236-246, 2017.

[25] G. Besagni, L. Croci, R. Nesa and L. Molimaroli, "Field study of a novel solar-assisted dual-source multifunctional heat pump," Renewable Energy, vol. 132, pp. 1185-1215, 2019.

[26] M. Dannemand, B. Perers and S. Furbo, "Performance of a demonstaration solar PVT assisted heat pump system with cold buffer storage and domestic hot water storage tanks," Energy \& Buildings, Vols. 188-189, pp. 46-57, 2019.

[27] D. A. Waddicor, E. Fuentes, M. Azar and J. Salom, "Partial load efficiency degradation of a water-towater heat pump under fixed set-point control," Applied Thermal Engineering, vol. 106, pp. 275-285, 
2016.

[28] J. Prakash, D. Roan, W. Tauqir, H. Nazir, M. Ali and A. Kannan, "Off-grid solar thermal water heating system using phase-change materials: design, integration and real environment investigation," Applied Energy, vol. 240, pp. 73-83, 2019.

[29] J. R. Brownson, "Chapter 03 - Laws of Light," in Solar Energy Conversion Systems, Cambridge, Academic Press, 2014, pp. 41-66.

[30] R. Green, "The Effects of Cycling on Heat Pump Performance," EA Technology Ltd, Capenhurst, 2012.

[31] G. Besagni, L. Croci, R. Nesa and L. Molimaroli, "Field study of a novel solar-assisted dual-source multifunctional heat pump," Renewable Energy, vol. 132, pp. 1185-1215, 2019.

[32] Y. Bai, T. T. Chow, C. Ménézo and P. Dupeyrat, "Analysis of a Hybrid PV/Thermal Solar-Assisted Heat pump System for Sports Center Water Heating Applications," International Journal of Photoenergy, vol. 2012, 2012.

[33] M. Dannemand, B. Perers and S. Furbo, "Performance of a demonstaration solar PVT assisted heat pump system with cold buffer storage and domestic hot water storage tanks," Energy \& Buildings, Vols. 188-189, pp. 46-57, 2019.

[34] A. Zarrella, G. Emmi, J. Vivian, L. Croci and G. Besagni, "The validation of a novel lumped parameter model for photovoltaic thermal hyvrid solar collectors: a new TRNSYS type," Energy Conversion and Management, vol. 188, pp. 414-428, 2019.

[35] P. Das, J. Mathur, R. Bhakar and A. Kanudia, "Implications of short-term renewable energy resource intermittency in long-term power system planning," Energy Strategy Reviews, vol. 22, pp. 1-15, 2018 